\title{
Beyond the economics of the euro: Analysing the institutional evolution of EMU 1999-2010
}

\author{
Marion Salines \\ (European Central Bank) \\ Gabriel Glöckler \\ (European Central Bank) \\ Paola del Favero \\ (European Central Bank) \\ Zbigniew Truchlewski ${ }^{1}$ \\ (Central European University)
}

\begin{abstract}
This paper examines how and why the institutional framework governing EMU has evolved since the creation of the euro. Building on theories of institutionalism, the paper in particular investigates to what extent functional spill-overs from the single currency to other policy domains, like macroeconomic policies or financial regulation, met with an adequate institutional response, and to what extent the existing institutional framework conditioned the response to the financial crisis. The interaction between policy requirements and institutional capabilities is examined both in "ordinary" times (19992007) and under "crisis conditions" (2007-2010). The paper uses a typology of change which helps to put into perspective both the resilience of the institutional framework of EMU and its capacity to adapt. In this respect, it allows for a better understanding and framing of the current reforms of EMU economic governance. It concludes that even though the crisis will accelerate institutional development, it will do so only in a gradual way, as path dependence and inbuilt bias towards incremental change will prevent policymakers pursuing a "clean slate" strategy.
\end{abstract}

JEL code: D79, E02, F02, F51, F53, F55, F59.

Keywords: EMU institutional architecture, historical institutionalism, rational choice, institutional change.

\footnotetext{
${ }^{1}$ The opinions expressed in this paper are those of the authors and do not represent the views of the European Central Bank. Any errors or omissions are exclusively the responsibility of the authors. The authors would like to thank Wouter Coussens, Jonathan Yiangou, Stefan Huemer, Gilles Noblet, Ludger Schuknecht, Johannes Lindner and Simon Usherwood for their comments and Anja Leskarac for research assistance. Correspondence: marion.salines@ecb.europa.eu; gabriel.glockler@ecb.europa.eu, paola.delfavero@ecb.europa.eu; Truchlewski_Zbigniew@ceu-budapest.edu
} 


\section{Non-technical summary}

This paper investigates the institutional dynamics of Economic and Monetary Union (EMU) since its inception in 1999. The analysis rests on the premise that "institutions matter", for institutions played a key role in generating distinctive policy outcomes and thus help to better understand the current strengths and shortcomings of the EMU framework.

The paper aims to explore the following questions:

- Did the increased economic and "political” (in the sense of carrying out policies) interconnectedness among euro area countries deriving from the shared use of the single currency meet with an adequate institutional response in terms of common economic governance structures?

- What types of institutional change did we observe during the first decade of EMU?

- To what extent did the existing institutional set-up condition the crisis response at EU/euro area level? In particular, did it succeed in mediating and shaping national interests to the benefit of the common interest of the EU and the euro area as a whole?

- What lessons can be drawn from the crisis that severely stress-tested EMU? Will the EMU institutional set-up change significantly and shift to a new development path as a result of this experience?

While mainstream political economy approaches to EMU consider mainly new modes of governance (e.g. "soft" coordination, informal governance), the present paper tackles these questions by applying state-of-the-art institutionalist theories to understand the role of institutions in generating the distinctive trajectory of EMU. In addition, it resorts to a typology of institutional change as developed by Thelen and Streeck (2005) to capture the types of institutional change that EMU has undergone.

The institutional dynamics of EMU, and in particular the interaction between policy requirements and institutional capabilities, is examined both in "ordinary" times (19992007) and under "crisis conditions" (2007-2010). As regards the first period, the paper analyses the incremental nature of the changes which the EMU framework has undergone using the concepts of layering and redirection, while at the same time aiming to capture in what way these changes were insufficient to effectively cope with the new quality of economic interconnectedness across Member States. In line with the predictions of institutionalism, the paper shows that institutional choices made in Maastricht have largely determined the path of the institutional evolution of EMU over the first eight years. Some 
institutional features of the Maastricht blueprint, especially the way common rules were applied and enforced, proved ex post not to be fully adapted to the functioning of a monetary union. However, these deficiencies did not come to the fore during the first eight years of EMU, not least given the favourable economic conditions.

In "crisis times" (August 2007- September 2010), the paper focuses more specifically on the respective role of Union institutions and Member States' interests in shaping the crisis response. The assumptions of institutionalism are once again verified: Union institutions did play a significant role in remedying the 'collective action dilemma' and in shaping Member States' behaviours during the first part (2007-2009) of the financial crisis. By contrast, the sovereign debt crisis which erupted in 2010 exemplified how an institutional framework based on decentralised policy-making, soft coordination and weak enforcement of common rules can be insufficient to effectively manage the interplay between competing domestic interests under severe market stresses.

Finally, the paper concludes that, even though the crisis will accelerate the institutional development of EMU (as witnessed by the creation of the ESRB/ESFS and EFSM/EFSF), it will do so in a gradual way, as path dependence and inbuilt bias towards incremental change will prevent policy-makers pursuing a "clean slate” strategy. 


\section{Introduction}

"The $10^{\text {th }}$ Anniversary of the euro is an opportunity (...) to celebrate an impressive and historic achievement"

(Bernanke 2008: 282)

"The more the crisis in the euro area develops, the more the last ten years seem to have been an artificial paradise"

(Pisani-Ferry 2010) $^{2}$

Looking back at the first twelve years of EMU, the assessments by scholars and policymakers of the performance of EMU has undergone remarkable shifts. Starting from the uncertainty surrounding its launch, the general assessment of EMU went through a period of praise, which was followed again by widespread uncertainty due to the current crisis (Buti and Gaspar 2008).

Prior to the launch of the euro, EMU was seen as a "high-stakes experiment" (Hodson 2010), where "success could not be taken for granted" (Buti and Gaspar 2008). Initial scepticism was particularly deep outside Europe. Many American scholars expressed strong doubts about the virtues of monetary integration in Europe, its economic feasibility and political viability. The possibility of a euro-area break-up has been debated in the US from the very beginning of EMU (e.g. Feldstein 1997; Tobin 1998). At the origin of this scepticism was - among other things - the fundamental asymmetry on which the EMU institutional set-up was based. Unlike in the previous attempt to establish Economic and Monetary Union in Europe - the 1970 Werner plan - which foresaw, in addition to a federal central bank, a "centre of decision-making for economic policy” (Werner Report 1970: $12-13^{3}$ ), the Maastricht Treaty embodied a conscious and fundamental political choice not to create a fully-fledged economic union: with the creation of the euro in 1999, monetary and exchange rate policies were transferred to the euro area level, while economic policies (such as fiscal or structural policies) largely remained within the remit of Member States and became subject to coordination procedures. This was mainly due to the fact that national governments saw these policies as the remaining core of national sovereignty, and had a profound interest in maintaining a substantive involvement. The asymmetry of the institutional set-up was also justified both on economic and constitutional grounds. At the time, the argument rested on the application of the

\footnotetext{
${ }^{2}$ See foreword of Proissl, W. (2010), "Why Germany fell out of love with Europe”, Bruegel Essay and Lecture Series

${ }^{3}$ This centre of decision-making for economic policy was supposed to "exercise independently, in accordance with the Community interest, a decisive influence over the general economic policy of the Community. In view of the fact that the role of the Community budget as an economic instrument will be insufficient, the Community's centre of decision must be in a position to influence the national budgets”. Several ideas voiced in the Van Rompuy Task Force on an independent agency which would oversee national budget echo the ideas raised forty years earlier in the Werner Report.
} 
subsidiarity principle reflecting the economic rationale that the allocation of policy responsibilities to a higher, supranational level would only be justified if the Member States cannot achieve the set objectives by themselves, or if the Union for reasons of scale or effects is better placed to achieve them. In EMU, that meant that monetary policy, by nature of its singleness and indivisibility, could not suitably remain decentralised, and hence has been unified and handed to a supranational central bank, the ECB/Eurosystem. The same logic applied to the regulatory framework of the Single Market, since a common market requires a set of common rules together with credible enforcement or at least a joint agreement on the mutual recognition of national norms and standards. By contrast, fiscal policies, microeconomic, structural and prudential supervisory policies, as well as labour market and employment policies were left in the hands of national policy-makers, "since there [were] - for the time being - no compelling arguments that could justify a full transfer of these policy responsibilities to the [Union] level.” (emphasis added, ECB 2001). Policy decentralisation was seen as providing national authorities with flexibility and vital room for manoeuvre while preventing negative externalities through implicit coordination via deficit and debt ceilings. In addition, it offered scope for the beneficial effects of healthy policy competition and for the emergence of best practices that could be emulated.

On the occasion of the $10^{\text {th }}$ anniversary of the euro, both academics and policy-makers conducted numerous stock-taking exercises. The overall evaluation of EMU after its first decade was largely positive. Even outside the euro area, the euro was described as “spectacular” (Bergsten 2005: 28) and an “indisputable success” (Posen 2009: 85). However, some warned that the euro was a "fair-weather currency", the true test of which was yet to come (see Dominguez 2006).

Interestingly, this general praise continued during the first stage of the crisis (2007 until late 2009), where the euro was often described as a shield which protected the 16 euro area countries from speculation and currency crisis - as had happened in the early 1990s. Till late 2009, many observers concluded that EMU had passed the test of the global financial crisis (Jaillet and Pisani-Ferry 2010). Within only a few months, the general perception moved from “where would we be without the euro?” (Martens and Zuleeg 2008) to “will EMU survive?”. With the advent of the sovereign debt crisis in early 2010, the break-up debate intensified, and many arguments that were made in the context of the feasibility debate surrounding the launch of EMU were again brought to the forefront, 
with the voices of the "We-told-you-this-will-never-work" faction of the commentary gaining important ground in the argument ${ }^{4}$.

Critical voices in the first eight years of EMU had mainly focused on the comparably overall mediocre economic performance of the euro area, while rarely commenting on the economic policy framework. During the crisis, by contrast, and especially with the onset of the sovereign debt crisis, concerns of observers moved beyond economics, to also touch upon the institutional and political capacity of the euro area governance framework to deal with the crisis and its implications. This sudden focus on, and acute awareness of perceived insufficiencies of, the institutional setting during the crisis is best exemplified by the significant attention that the debate on economic governance has attracted, and continues to attract. ${ }^{5}$

In fact, the trajectory of EMU had neither been dictated by market forces nor been the fruit of mere coincidence. This paper argues that institutions played a key role in generating distinctive policy outcomes. Based on the premise that "institutions matter", a review of the first twelve years of EMU from an institutionalist perspective can help to better explain how the institutional framework governing EMU has developed since the creation of the euro and identify the reasons behind the relative inertia and gradualism of its evolution. This paper explores the dynamics of this evolution and the role of institutions, with recourse to new institutionalist theories as a conceptual background. Hereby, "institutions" are defined in a very broad sense and encompass formal and informal procedures, rules, interaction, etc. For the purposes of the analysis, it is opportune to distinguish between the performance of the EMU institutional framework in "ordinary" or "fair-weather" times (1999-2007) as well as under "crisis conditions" (August 2007- September 2010). The analysis covers the period until September 2010 (publication of Commission proposals for economic governance). While a number of momentous economic and institutional developments have happened since then, a certain cut-off date needs to be defined in order to maintain a clear focus of the analysis. References to specific developments since that cut-off date are included where this adds value to the arguments presented.

\footnotetext{
${ }^{4}$ See for example S. Brittan, 2010 “The futile effort to save the eurozone”, Financial Times, 4 November ("If something is unsustainable, it will not be sustained") or Christopher Smallwood, 2010 "Why the euro zone needs to break up", Capital Economics ("For the sake of the future economic health and success of the European Union, the euro-zone needs to break up.”),

${ }^{5}$ The Van Rompuy Task Force (VRTF) was set up in March 2010 and delivered its report on 21 October 2010. The European Central Bank came up with proposals in June 2010, and the Commission published six legislative proposals on 29 September 2010.
} 
With regard to the "fair-weather" period (1999-2007), the possibly extraordinary period of low macroeconomic volatility in the early years of the euro, we aim to explore the following questions:

- Did the increased policy interconnectedness deriving from the shared use of the single currency meet with an adequate institutional response on the part of the institutions of economic governance?

- What types of institutional change did we observe?

- To what extent did previous institutional choices determine the path of the institutional evolution?

- $\quad$ How to explain this distinctive trajectory?

The crisis period since 2007 put severe pressure on the operation of the institutional framework, motivating a different set of questions, namely:

- $\quad$ To what extent did the existing institutional set-up condition the crisis response at EU/euro area level?

- In particular, did it succeed in mediating and shaping national interests to the benefit of the common interest of the EU and the euro area as a whole?

- What lessons can be drawn from the crisis that severely stress-tested EMU?

- Will the EMU institutional set-up undergo a more dramatic change and shift to a new development path as a result of this experience?

In seeking to answer these questions, the paper is structured as follows. Section 2 lays down the conceptual framework applied throughout the paper and explains its relevance. Section 3 explores the evolution of the EMU framework in “ordinary times” (1999-2007), while Section 4 analyses the reaction of EMU to the crisis during "extraordinary times" (2007-2010). Section 5 attempts to draw some lessons from the first twelve years of existence of EMU and discusses the likely evolution of the EMU institutional framework in the aftermath of the crisis.

\section{Why institutions matter: explaining the evolution of EMU through the institutionalist lense}

Since the inception of the Euro, the institutional architecture of EMU displayed both continuity and change. How can we account for the changes observed and their impact on 
the economic governance of the EMU? Classical economics alone cannot fully explain them. Even if economic reasons were the trigger of change, they alone cannot account for the particular form of institutional change that occurred. Why did some institutions fare better than others in the EMU framework? Why did new institutions emerge while others became marginalised? North and Weingast (1989) gave an important example of how institutions impact the economy with their study of the Glorious Revolution, thereby complementing and expanding a perspective based purely on the uncritical acceptance of neoclassical economics. For "neoclassical theory is concerned with the allocation of resources at a moment of time, a devastatingly limiting feature to historians whose central question is to account for change over time. Moreover, the allocation was assumed to occur in a frictionless world, that is, one in which institutions either did not exist or did not matter” (North 1990: 131).

On the other hand, mainstream political economy approaches to EMU have also been partial, and have not really undertaken a comprehensive examination of the whole institutional set-up ${ }^{6}$. They have proved to be static and have neither captured nor explained institutional change or lack thereof. ${ }^{7}$ This is what this paper aims to achieve with the analytical tools provided by the new institutionalist approach.

\subsection{The relevance of the new institutionalist approach}

In political science, this new theoretical approach emerged in the 1980s partly in reaction against behavioural perspectives. Its main assertion is that institutions do matter in determining decisional outcomes (Nugent 2006: 572). An institutionalist perspective can help to better understand both the resilience and the degree of adaptability of the EMU institutional architecture. It looks at the institutional organisation of the polity or political economy as the main factor structuring collective behaviour and generating distinctive outcomes (Hall and Taylor: 937). It can measure "big structures, large processes and [make] huge comparisons” (Tilly 1984) ${ }^{8}$, based on the key assumption that institutional development is dominated by path dependency.

"Once actors have ventured far down a particular path, they are likely to find it very difficult to revert course. The path not taken or the political alternatives that were once quite plausible may become irreversibly lost. "Path dependence analysis" highlights the role of "historical causation" in which dynamics triggered by an event

\footnotetext{
${ }^{6}$ For an early critique of the governance approach, see Dyson (2000: 106-108).

${ }^{7}$ For a balanced and nuanced account of the strength and weaknesses of the principal-agent approach as applied to EMU governance, see Hodson (2009b).
} 
or a process at one point in time reproduce themselves, even in the absence of the recurrence of the original event or process. " (Pierson \& Skocpol 2002)

The institutionalist approach can offer useful insights to elucidate the institutional trajectory of EMU from 1999 to 2007.

Institutionalism ${ }^{9}$ is also "fit for purpose" to explore the policy response to the crisis (20072010),as another strand of research of new institutionalism investigates the extent to which and the ways in which institutions shape, channel and constrain the rational choices of political actors (Nugent 2006: 573). Applied to the process of European integration, this approach can explain the motivations of national governments to engage further in the process of European unification despite the implied loss of competences, and to demonstrate the consequences of different EU decision-making rules for political actors' behaviour (Nugent 2006: 573). It is based on three main assumptions (Hall and Taylor 1996: 944-945). First of all, as in the microeconomic rational choice theory, the relevant actors have a fixed set of preferences and behave rationally so as to maximize their utility. Second, politics is a series of collective action dilemmas: with each political actor acting to maximize the attainment of its own preferences, the outcome is likely to be collectively suboptimal. Third, institutional arrangements can serve as a remedy to this problem by influencing actors' behaviours. In particular, they can shape the actors' expectations about how others are likely to behave and thereby shape their strategic calculations.

The crisis has led to a multiplication of 'collective action dilemmas' in EMU, because a more robust pursuit of the national interest usually comes to the fore in crisis times. This is because "in difficult economic times the comfortable illusion [that the economy works with sufficient regularity] disintegrates, [...] economic models come into conflict, and policy prescriptions diverge.” (Gourevitch, 1986) ${ }^{10}$ By looking at the “crisis times” through the lenses of institutionalism, the paper will seek to explain patterns of policy response and the resulting outcomes.

\footnotetext{
${ }^{8}$ Big structures, large processes and huge comparisons, Tilly, 1984

${ }^{9}$ As explained by Hall and Taylor (1996), rational choice institutionalism originated in the observation of a paradox in the political behaviour of the US Congress. The traditional rational choices' approach would lead to the conclusion that it is virtually impossible to secure stable majorities for passing legislation in the House of Representatives and the Senate. However, Congressional outcomes actually show considerable stability. To explain this paradox, rational choice institutionalists turned their attention to institutions and demonstrated how the rules of Congress affect the behaviour of legislators, reduce the transaction costs and solve many of the collective action problems with which a parliament is usually confronted.

${ }^{10}$ For a historical overview of politics during economic crises, see Gourevitch (1986).
} 


\subsection{A typology of institutional change applied to EMU}

Institutions can be viewed as comparable to biological bodies that are "not perfectly designed organisms” but are constantly adapting and evolving, thus producing variation, incremental changes or ruptures at critical junctures (Steinmo and Lewis 2007). Precisely because "institutions matter" - in particular their relative inertia or adaptation - in explaining the evolution of EMU, it is useful to develop a more detailed typology of institutional change to better describe the developments observed over the past decade. The paper will thus draw on the following typology developed by Streeck and Thelen (2005):

- layering is an institutional change which happens when new institutional elements are added to existing ones. Applied to the EMU context, this process can be seen in the successive addition of institutions (such as the EFSM/EFSF or the "codification" of the Eurogroup in the Lisbon Treaty), processes (creation of Lisbon agenda and related process) and policy instruments (Art. 136 TFEU decision addressed to Greece).

- displacement takes place when an element of the institutional setup gains more salience over time. The ECB provides an interesting instance of "displacement": the ECB's role has been more and more prominent since the eruption of the crisis, first with measures on the financial markets in August 2007, then with the Securities Market Programme (SMP) to ensure a proper transmission of monetary policy during the sovereign debt crisis and a strong voice in the debate on governance reform.

- redirection occurs when an institution has its parameters changed and its objectives reoriented, be it in a fundamental way or in a marginal manner. A example of such a change is the Stability and Growth Pact which has gone beyond being a mere disciplinarian device (limiting borrowing of Member States to ensure the sustainability of EMU and to prevent harmful spill-over between Member States and between fiscal and monetary policy) to a more wide-ranging instrument to steer broader aspects of budgetary policy (increasing its focus on the long-term sustainability of public finance and pensions, as well as on the quality of public finances and domestic institutional frameworks like rules or medium-term frameworks).

- drift happens when institutional setups are overwhelmed by external developments. Such a case can be found in the discrepancy between financial integration which proceeded apace and the elaboration of a financial supervision, which remained fragmented.

- depletion can be identified when institutions experience a gradual breakdown over time. Obviously, this variety of gradual change hardly applies to EMU since it is still a relatively young "institution”. 
This typology of institutional change needs to be complemented by a review of the drivers of institutional change. While the mainstream literature usually focuses exclusively on path dependency, overstating permanence and then being unable to explain change, Lindner (2003) aptly reverses the arguments by asking what produces institutional stability. He argues that the analysis of institutional stability provides the key for explaining the emergence of institutional change. He identifies four 'reproduction mechanisms': the bargaining power of the anti-change coalition; the interdependence between policy sub-fields; the costs of switching to another institutional setting; the ability to accommodate pressure for change through minor adaptations. Institutional change comes about only when these reproduction mechanisms break down.

Table 1. Varieties of gradual change ${ }^{11}$

\begin{tabular}{|c|c|c|c|c|c|}
\hline & Layering & Displacement & Redirection & Drift & Depletion \\
\hline Definition & $\begin{array}{l}\text { New elements } \\
\text { added to } \\
\text { existing } \\
\text { frameworks } \\
\text { change slowly } \\
\text { their structure }\end{array}$ & $\begin{array}{c}\text { Some } \\
\text { institutions gain } \\
\text { more salience } \\
\text { overtime }\end{array}$ & $\begin{array}{l}\text { Old institutions } \\
\text { get new } \\
\text { objectives on top } \\
\text { of their old ones }\end{array}$ & $\begin{array}{c}\text { Institutions } \\
\text { adapt } \\
\text { insufficiently to } \\
\text { external change }\end{array}$ & $\begin{array}{l}\text { Institutions } \\
\text { wither away }\end{array}$ \\
\hline $\begin{array}{c}\text { Drivers of } \\
\text { stability/ } \\
\text { change }\end{array}$ & \multicolumn{3}{|c|}{$\begin{array}{l}\text { Pressure for change accommodated by } \\
\text { small on-path changes }\end{array}$} & $\begin{array}{l}\text { Lack of actors } \\
\text { interest in } \\
\text { change; } \\
\text { important } \\
\text { switching costs }\end{array}$ & $\begin{array}{c}\text { Failure of } \\
\text { reproduction } \\
\text { mechanisms }\end{array}$ \\
\hline $\begin{array}{l}\text { Example in } \\
\text { EMU }\end{array}$ & $\begin{array}{c}\text { Eurogroup } \\
\text { “codification” } \\
\text { in the Lisbon } \\
\text { Treaty; } \\
\text { EFSF; } \\
\text { ESRB; } \\
\text { Extension of } \\
\text { surveillance } \\
\text { mechanisms }\end{array}$ & $\begin{array}{l}\text { ECB took the } \\
\text { "lead" during } \\
\text { the crisis as } \\
\text { crisis } \\
\text { "manager": } \\
\text { providing } \\
\text { liquidity, SMP }\end{array}$ & $\begin{array}{c}\text { SGP and } \\
\text { budgetary } \\
\text { surveillance } \\
\text { redirected } \\
\text { towards } \\
\text { sustainability } \\
\text { and set to take } \\
\text { into account } \\
\text { imbalances }\end{array}$ & $\begin{array}{c}\text { Financial } \\
\text { supervision: } \\
\text { Lamfalussy } \\
\text { process. } \\
\text { Competitivenes } \\
\text { s framework }\end{array}$ & None \\
\hline
\end{tabular}

\section{Plain sailing? EMU in fair-weather times (1999-2007)}

This section identifies and examines through the lenses of institutionalism the varieties of institutional change of EMU's framework in "fair-weather times". EMU institutional dynamics during the first decade can be subsumed into two groups: the first one, which reflects the concept of spill-over effects through layering and redirection, represents the slow and incremental adaptation of the institutional architecture of EMU to internal and external pressures, like the SGP crisis of 2003-2005. The second one, embodied by the logic of resistance and path dependence, shows how institutions faced difficulties to adapt because of the long-lasting and locked-in effects of the institutional choices made in Maastricht. We analyse both groups in turn in this section in the light of the first decade of EMU.

${ }^{11}$ Adapted from Streeck and Thelen (2005: 31). 


\subsection{How the EMU institutional architecture adapted incrementally: layering and redirection}

Since the Maastricht Treaty, EMU institutional architecture evolved mainly by the process of layering and redirection, because of institutional frictions and spill-over effects stemming from the asymmetric structure of EMU. This resulted into continued efforts over time to put more flesh on the "E” of "EMU” even before EMU came to reality. In the words of the Delors report, this is because "Economic and Monetary Union form two integral parts of a single whole and would therefore have to be implemented in parallel”12.

A first step was taken to reinforce economic governance with the creation of the SGP which was signed in 1997. It was designed to build on and clarify a framework for sound budgetary policies and to avoid free riding. It was also useful to clarify the Excessive Deficit Procedure of Article 126 of the TFEU. On top of that came the Eurogroup which provides an informal forum for Finance Ministers from the euro area (see Puetter 2006).

Simultaneous steps were taken to reinforce the coordination of structural economic reforms on the supply side. Yet, while the SGP was mainly based on "hard coordination" through "hard law", structural coordination was "soft" because it relied on a new institutional layer dubbed the "Open Method of Coordination" (OMC). Contrary to the traditional Union method which relies on the Commission as agenda-setter, voting by the Council and the European Parliament and the interpretation of law by the European Court of Justice, the OMC is a "heterarchical, decentered and dynamic process [which] supports and radicalizes the principle of subsidiarity” (Hodson and Maher 2001: 719). The coordination of structural reforms is important because of potential spill-overs that can happen between these policy areas and the fiscal and monetary domains. Thus economic spill-overs can become political spill-overs in the form of new institutional processes. The coordination of these reforms was supposed to be achieved through processes like those of Luxembourg (1997 - labour market reforms), Cardiff (1998 product and capital market reforms) and Cologne (1999 - macroeconomic dialogue involving social partners). These processes were streamlined in the Lisbon strategy of 2000 which set goals for the creation "of the most competitive economy in the world" by 2010. This process was reformed in 2005 and further refined in 2010 with the EU 2020 economic strategy.

${ }^{12}$ Delors Report, 1989: paragraph 21. 
Chart 1. Institutions \& bodies in EU/euro area economic governance

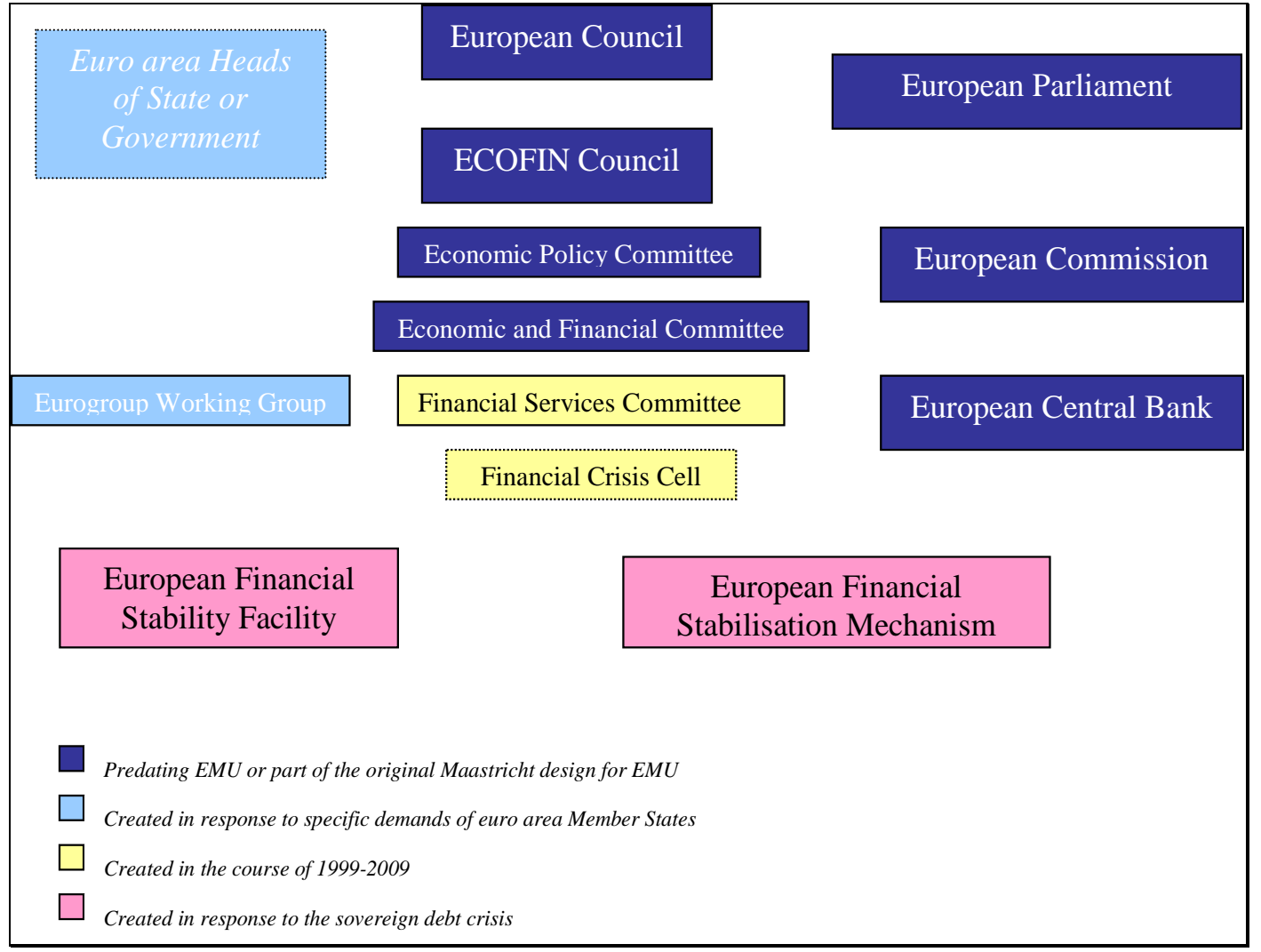

This process of institutional layering of economic governance came on top of the Broad Economic Policy Guidelines (BEPGs). The BEPGs exist as such since 1993 but have a prehistory which goes back to the Treaty of Rome when the Monetary Committee started to publish country recommendations in 1959 (see Deroose, Hodson and Kulhmann 2008). The BEPGs also represent a form of path dependency: the creation of a Medium-Term Economic Policy Committee in 1964 issued guidelines which were also later the main instrument to coordinate economic policies in order to implement the EMU (article 99.2 of the Maastricht Treaty). In fact, the first BEPG of 1993 were the core of a nascent multilateral surveillance, a framework to assess Member States' convergence programmes to EMU and a way for the Member States to commit to EU economic policy objectives. BEPGs were subsequently used in the Lisbon process. One can thus conclude that "looking back, it is clear that the first BEPGs articulated the essential features of EU's economic policy strategy over the next decade” (Deroose, Hodson and Kuhlmann 2008: 830) because they foreshadowed the provisions of the SGP and the objective of price stability.

The description of institutional change of EMU economic governance framework would be incomplete without looking at the diverse processes of policy learning, policy transfer 
and institutional transplants which complete the layering process of the governance framework of EMU at the domestic level. A key process which is taking place concerns the reform of national fiscal frameworks which internalizes the necessities of participating in EMU at the domestic level. A key policy learning process and institutional transplant is to be identified in the case of debt rules and the constitutionalisation of budgetary balance. In the midst of the crisis Germany tightened the "debt brake” which limits net borrowing by the Federation and the Länder and which aims to bring the structural deficit to $0.35 \%$ of GDP by 2016 (Kastrop et alii 2009). This reformed German rule sparked a heated debate in France where comparable proposals were put on the table (Delpla 2010 and Bouzou 2010). This precise case of policy learning occurs in the broader context of the open method of coordination where benchmarking, consensus and exchange of policy experiences come to the foreground: what one witnesses is in fact the process of trial-anderror where observations from policy successes and failures leads to consensus formation and policy emulation (e.g. "Danish flexicurity"13)

This last example on fiscal governance provides a useful insight on institutional redirection. The original SGP was a disciplinary device which was supposed to prevent over-expansionary fiscal policies on the one hand and to co-ordinate national budgets on the other. Yet the SGP reform of 2005 and subsequent developments redirected its logic in two ways. First it extended budgetary surveillance horizontally by focusing more on the long-term perspective and on fiscal "sustainability": the debt criterion becomes more important than the deficit, and more attention is paid to pension systems and implicit liabilities (see European Commission 2006a: 126). Second it extended budgetary surveillance vertically by looking at the composition of public expenditure in Member States Budget and by fine-tuning the SGP to national conditions with country-specific medium-term objectives (Schelkle 2009). It also shifted from a mere implementation of the SGP on the supranational level to an insistance on the need to have strong fiscal frameworks at the national level and to increase national ownership of European objectives. Hence the three new agendas of budgetary surveillance which emerged step by step: reports on fiscal sustainability in 2006 and 2009 investigating long-term expenses

\footnotetext{
${ }^{13}$ In fact, this process of policy learning is supported by the increasing importance of databases and more effective methodologies of surveillance (Deroose, Hodson and Kuhlmann 2008). Since 2005, EU LABREF aims at gathering information on labour market reforms in EU Member States (employment-protection legislation, unemployment and welfare related benefits, active-labour-market programmes and labour taxation). Since 2007, EU KLEMS gives the possibility to consult data on productivity development at the industry level for EU Member States since the 1970s (Koszerek et al. 2007). The LIME Working Group of the Economic Policy Committee, which involves Commission and National officials, works on developing methods to measure the progress of structural reforms. The most recent database concerns national fiscal frameworks. Established in late 2009, it provides useful information on fiscal rules, independent fiscal institutions and on medium budgetary frameworks in EU Member States. It draws on yearly questionnaires sent to national finance ministries which further specify institutional characteristics of their national fiscal frameworks.
} 
related to pensions systems (European Commission 2009d); the focus on the "quality of public finance” to which a Working Group of the EPC is dedicated (Schaechter and Barrios 2008); and the analysis of the political economy of domestic fiscal regimes and their efficiency (European Commission 2006 and the subsequent yearly Public Finance Reports of the Commission). The results of this work show that domestic fiscal regimes have been strengthened over time, notably by a more extended use of fiscal rules. This last point can be measured by the fiscal rules index of the Fiscal Governance Database of the European Commission (see Chart 2).

Chart 2. Evolution of domestic fiscal governance in the EU

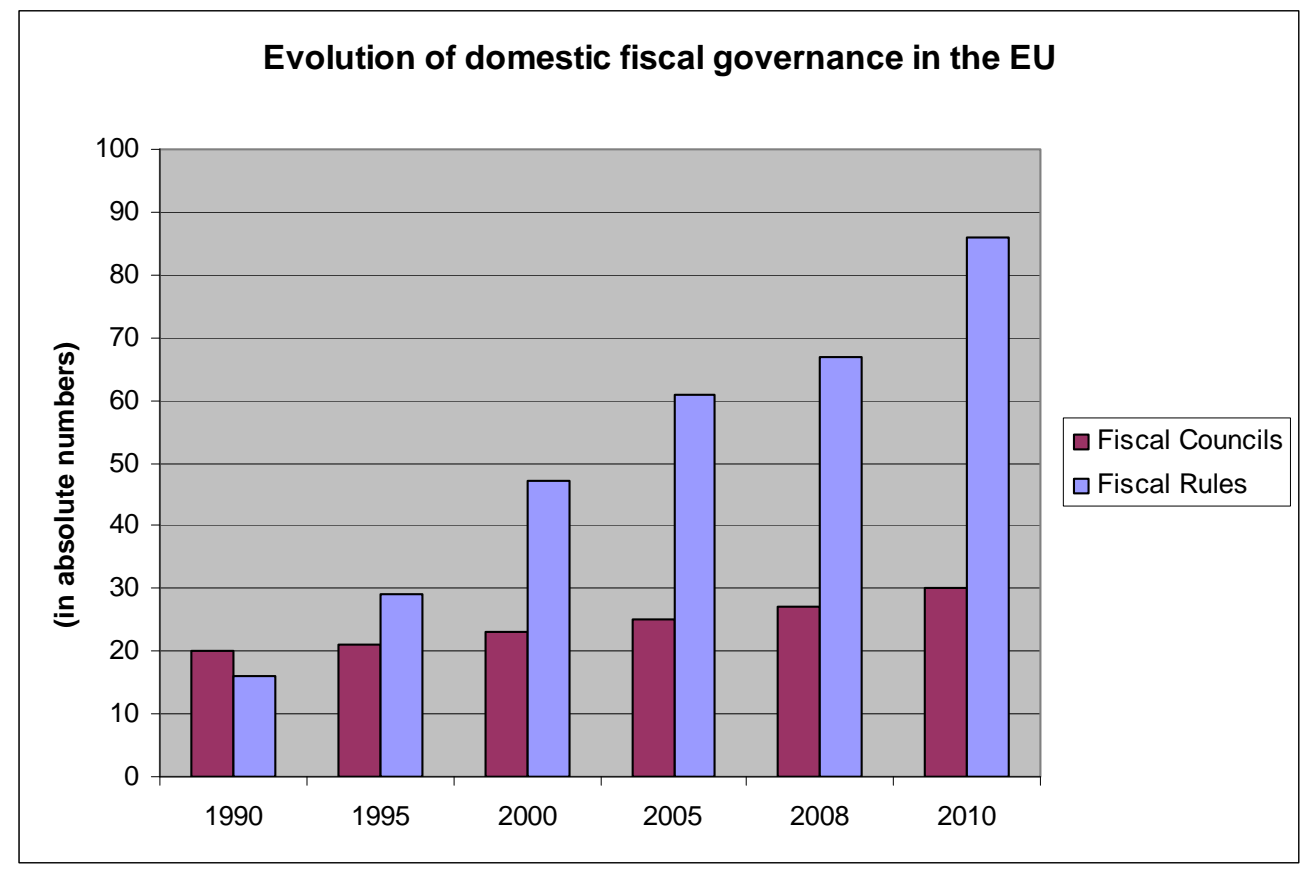

Source: European Commission, Fiscal Governance Database

The dynamics of financial supervision in the EU also embody well the process of layering: "The Lamfalussy architecture is articulated across multiple institutional levels. At level 1, the EP and the Council co-decide framework legislation (directives) proposed by the Commission. At level 2, the implementing measures (generally directives, less frequently regulations) of the level 1 framework legislation are adopted by the Commission through the comitology process, which involves the so-called level 2 committees of member states representatives. At level 3, the committees of national regulators (the level 3 committees) advise the Commission on the adoption of level 1 and level 2 measures and adopt level 3 measures, such as non-legally binding standards and guidelines” (Quaglia 2008: 564). 
Chart 3. The Lamfalussy supervisory committees ${ }^{14}$

\section{The Lamfalussy structure of supervisory committees in the EU}

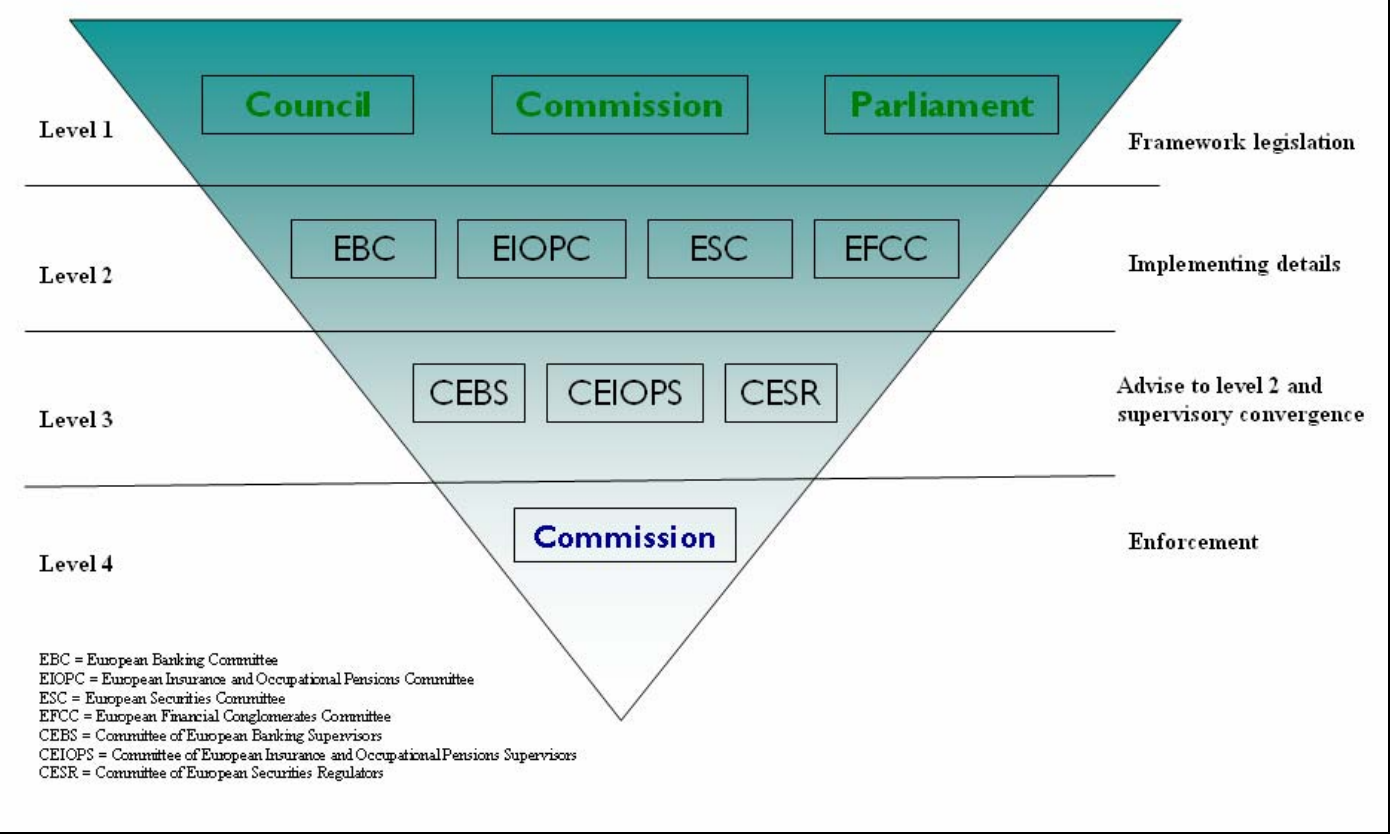

Finally, this process of institutional layering and expansion is also embodied by interinstitutional relations. EMU governance went through a process of "densification” which can be decomposed into four trends: (1) an increased frequency of interaction; (2) a broadening of the topics discussed within economic fora; (3) a deepening of the discussions with an increase of the ECB written contributions; and (4) an increase of areas of deliberations (European Central Bank 2010a and graphs 4 and 5).

${ }^{14}$ Adapted from De Haan, J., Oosterloo, S. and Schoenmaker, D., (2009), 54. 
Chart 4. Amount of documentation processed in EU governance fora (2003-2008)

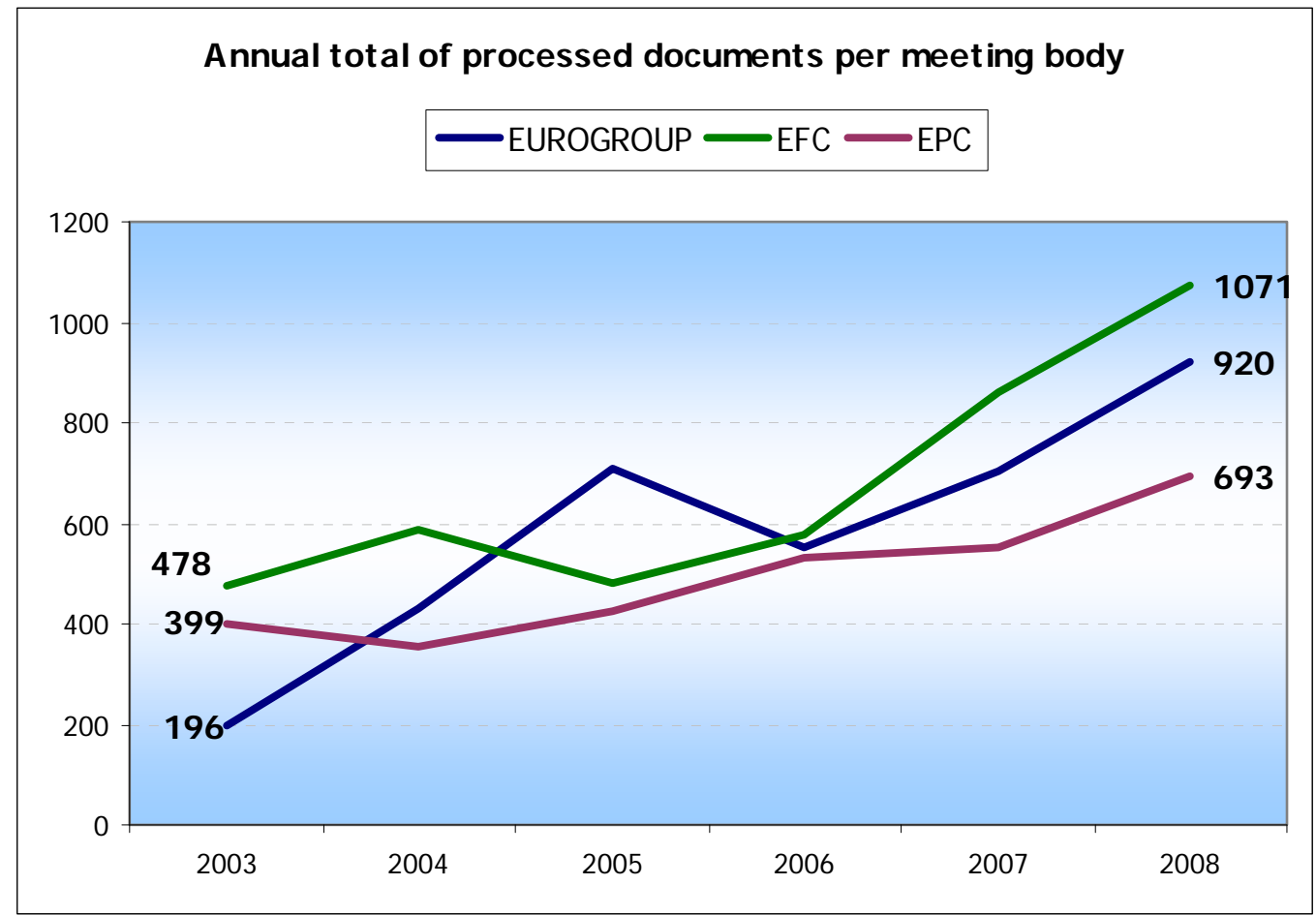

Chart 5. Number of meetings of economic governance fora (1999-2008)

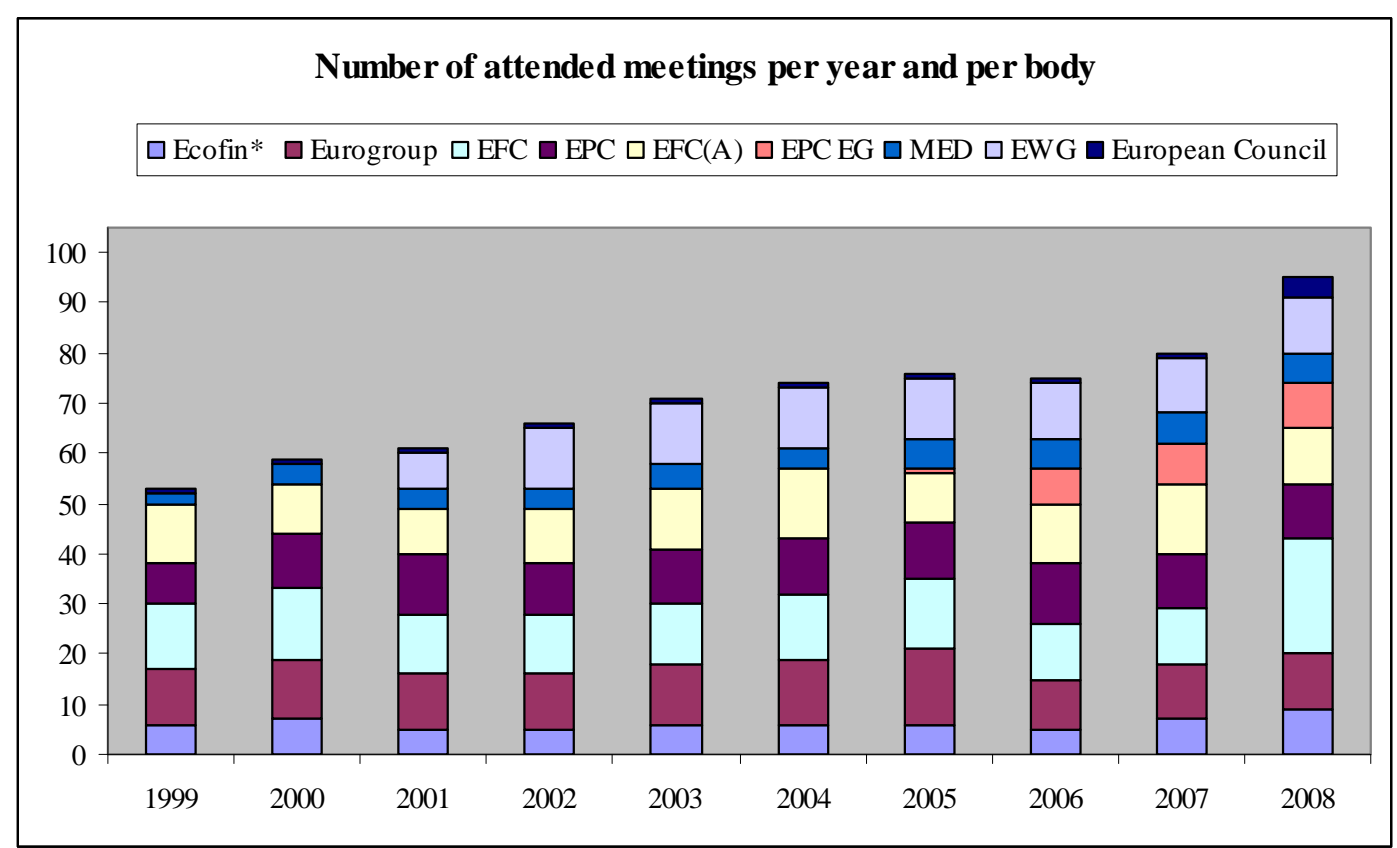

\subsection{Accounting for the path dependency of the EMU institutional architecture}

While a gradual adaptation of the institutional framework notably in response to functional spill-over effects can be observed, there is also evidence of resistance, stickiness and path dependence of EMU architecture, or, in other words, of insufficient adaptation to the increased level of interconnectedness within the euro area. Institutional 
layering reveals indeed some shortcomings in the institutional framework of EMU. The incremental changes were not sufficient to address the fundamental mismatch between the level of policy interconnectedness and the level of institutional development prevailing within EMU. While euro area economies have become more and more closely interlinked, the institutional set-up did not provide euro area Member States the right incentives, be it sanctions or rewards, to internalise the constraints of monetary union.

Concerning fiscal and macroeconomic surveillance, institutional layering did not prove to be optimal as demonstrated by diverging competitiveness developments across euro area Member States and the poor shape of public finances in some countries. Hence, while institutional layering proves the institutional resilience of the framework of EMU, it also sheds light on one shortcoming: its insufficient capacity to adjust fast and in an optimal manner to exogenous shocks and to credibly enforce the rules on which it is based. Cases in point are the BEPG which failed to stem the diverging competitiveness developments within the euro area (see Chart 6) and the SGP, which did not force Member States to bring national budgets "close to balance or in surplus".

\section{Chart 6. Evolution of unit labour costs across the euro area}

Unit labour costs in selected euro area countries, nominal (index 2000Q4 $=100$, relative to Germany, based on sa data)

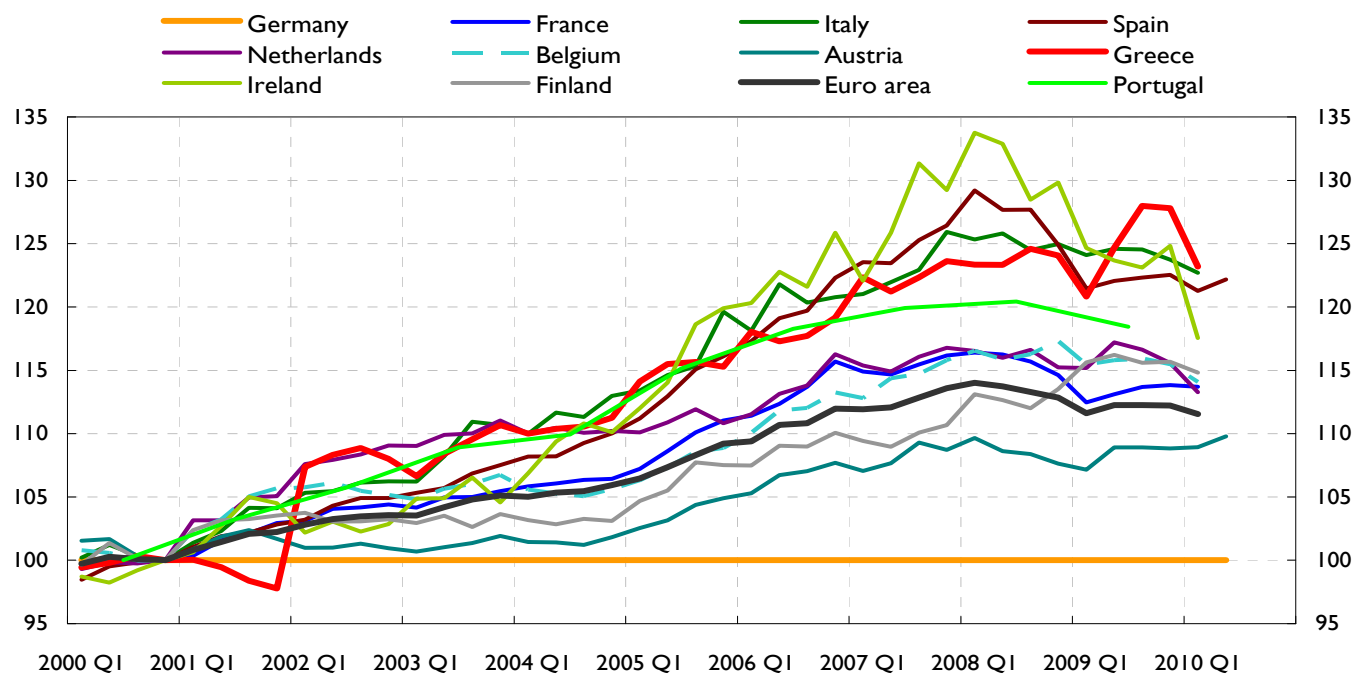

Source: Eurostat. Quarterly data up to 2010 Q1; 2010 Q2 for AT, DE and ES; PT is based on annual data (up to 2009). Note: The ULC indices are set to 100 in the last quarter before the euro area accession of Greece. The ULC developments presented for Greece and Portugal might differ from the calculations made by the National Central Banks. The quarterly pattern in Greek ULC is affected by substantial volatility in quarterly compensation of employees figures.

It could even be argued that EMU actually suffered a setback in 'fair-weather times'. As an example, while the revised SGP became more wide-ranging, it allowed for much more 
flexibility and discretion, thereby becoming de facto less binding. Similarly, the 2005 mid-term review of the Lisbon Strategy endorsed an approach involving more 'national ownership’ and neglecting benchmarking and peer pressure (Ioannou et al 2010; 14). The Member States used this concept of national ownership to limit any interference from the European level.

Another telling example of path dependency, resistance and institutional friction is to be found in the governance of financial markets in the euro area. In fact market integration outpaced institutional integration. Alexandre Lamfalussy, the former head of the European Monetary Institute, qualified financial governance as "suboptimal” (Lamfalussy 2004). This created institutional friction as EU financial integration stumbled upon what can be called a "financial trilemma": there is an in-built incompatibility between financial integration, financial stability and independent national supervision (Schoenmaker and Osterloo 2007). Institutional friction comes also from the fact that "the home country supervisors' mandate does not include co-responsibility for financial stability in partner countries but the host country authorities, whose mandate is to ensure financial stability, do not have authority for supervising financial institutions from partner countries unless they operate through independent subsidiaries” (Pisani-Ferry and Sapir 2010: 345).

As long as banks remained in the national realm, national regulators had an informational competitive advantage and thus blocked any transfer of competence to the EU. But while the emergence of pan-European banks made this argument less stringent, there were no supervisory arrangements which would give more clout to the EU level. Instead, institutional dynamics of financial supervision followed rather the logic of decentralization to national regulators, harmonisation of EU legislation, the creation of a European Committee of Banking Supervisors (CEBS) to ensure consultation between national regulators and technical advice to the Commission (Quaglia 2010).

All this demonstrates that the institutional choices made in Maastricht have largely determined the path of the institutional evolution of EMU over the first eight years. In fact, the Lisbon Treaty did not reform fundamentally EMU (see Frankal, Oleaga and Coussens, 2007) despite the fact that, as the successor of the late Constitutional Treaty, it was supposed to address concerns over economic governance expressed in the Laeken Declaration of the European Council in 2001. The Lisbon Treaty is a prime example of incremental institutional evolution. 
This lack of profound institutional change can be explained by the force of two 'reproduction mechanisms' (Lindner 2003), namely the lack of interest in change by the dominating actors and - paradoxically - the ability of the institutional set-up to accommodate pressure for change through small institutional alterations at the margin.

The former was exemplified during the negotiations of the new treaties - the late Constitutional Treaty and the now implemented Lisbon Treaty (Hodson 2009a: 520). First, Finance Ministers opposed any radical change in the institutional architecture of EMU, unwilling as they were to upgrade the Eurogroup to the full status of a Council formation and to give more power to the European Commission (Puetter 2007). Second, tensions between France and Germany over a potential political counterweight to the ECB slimmed down the chances for an overhaul of economic governance in the first decade of EMU. Finally, also the timing may have raised some hurdles: the Working Group on Economic Governance of the European Convention "met during a period of heightened tension over the enforcement of the Stability and Growth Pact” (Hodson 2009a: 520). In July 2003, the European Convention presented its draft Constitution. The Intergovernmental Conference (IGC) did so for the final draft in June 2004. Obviously, this overlaps with the vote to put the SGP “in abeyance” in November 2003 and the ruling of the ECJ in July 2004. In fact, "there was little appetite among the members of the European Convention's Working Group on Economic Governance to become embroiled in the controversy over the Stability and Growth Pact by calling for radical reforms to EMU’s institutional architecture” (Hodson 2009a: 520).

Most importantly, the relative stability of EMU over the first eight years can be explained by the ability of the institutional setting to accommodate pressure for change by small onpath changes (as described in Section 3.1). A number of incremental changes occurred to address the increased economic and political interconnectedness among euro area economies, but they did not go far enough to fully cope with it and paradoxically contributed to the stickiness of the institutional setting. Not least given the favourable economic conditions, the consequences of the mismatch between the policy requirements and the institutional capabilities did not manifest themselves in "fair weather" times.

The crisis time period, in contrast, may have proved to be a shot across the bows revealing the deficiencies of EMU's institutional framework. In the next section the focus of our analysis will move from institutional change per se to how the institutional framework structured and thus, to a certain extent, conditioned the crisis response. 


\section{Weathering the storm: EMU during the crisis (2007-2010)}

The financial turmoil has been largely recognised by observers as a litmus test for EMU. For the first time since its launch, the ability of EMU to batten down the hatches and react swiftly in a coordinated way to external shocks has been stress-tested on a massive scale. This presented a whole new set of challenges to EMU and its institutional set-up. This section attempts to capture the dynamics of EMU between 2007 and 2010 by taking a micro-perspective and focusing more specifically on the respective role of institutions and of Member States' interests in shaping the crisis response. The subsequent sections will successively analyse the response of EMU to the financial crisis (Section 4.1) and to the sovereign debt crisis (Section 4.2).

\subsection{Policy coordination initiatives during the financial crisis}

The situation in which the EU has found itself since the outbreak of the crisis has been characterised by numerous (positive and negative) spill-over effects from national policy actions in areas such as liquidity support, recapitalisation of banks and fiscal policy (Quaglia, Eastwood and Holmes 2009: 67). The EU has traditionally been based on a set of rules (e.g. competition policy), whose compliance is ensured by the Commission and the ECJ. However, the rule-based system in place at the beginning of the crisis was not tailored for such extraordinary circumstances. The coordination by the EU of national responses to the crisis could not revert to rules, and some discretionary action was thus required. This could have implied a severe risk of a vicious spiral of "beggar-thyneighbour policies” like in the 1930 s $^{15}$ - which the EU has successfully mitigated.

This is well illustrated by the Irish example (Glöckler 2009). Shortly after the collapse of Lehman Brothers, the Irish government announced a guarantee that would "safeguard all deposits, covered bonds, senior debt and dated subordinated debt” (Irish Ministry of Finance 2008) with six Irish financial institutions. This decision was aimed at avoiding bank runs and a meltdown in the domestic financial sector and was thus fully rational from an Irish political perspective. However, it ignored the potential "externalities" of this decision, notably the fact that Ireland, and the Irish financial system, are part of the euro area and EU financial market. If other EU countries had attempted to "maximize their utility" by announcing measures of that type, it would have led to a fragmentation of the integrated financial and money markets: savers would naturally have withdrawn their savings from

${ }^{15}$ Involving, inter alia, unilateral devaluations and the reintroduction of import levies. 
banks in countries where these were not guaranteed by the state and channelled them to banks in countries where they were. Would this spiral of financial sector "beggar-thyneighbour" measures have escalated, the integrated financial market would have refragmented and renationalised into individual national financial markets. The outcome would have been clearly sub-optimal from a pan-European perspective. The swift reaction of EU institutions contributed to remedying this problem - even though only partially. On 7 October 2008, the ECOFIN Council committed to take all necessary measures to protect the deposits of individual savers (EU Council 2008). A week later, the European Commission (2008d) brought forward a proposal to promote convergence of deposit guarantee schemes. It aimed at avoiding competitive distortions inter alia by increasing the minimum coverage level, and was adopted in March 2009. Nevertheless, this revised directive was not without limitations since it set a minimum, not a maximum, for such schemes in the Member States. In addition, it did not regulate guarantees in respect of nondeposit liabilities (Quaglia, Eastwood and Holmes 2009: 76).

A number of similar initiatives have been taken at the EU-level to ensure that the design of national stabilisation measures to resolve the financial turmoil does not lead to negative spill-over effects and that a level-playing field is maintained across the EU (see ECB 2010b). Those initiatives related mainly to a common agreement among euro area countries on guiding principles and common intentions for the design of national responses with a view to upholding the informal market. Specifically, the European Commission, in close cooperation with the ECB, provided guidance to Member States on the implementation of those principles, for instance with regard to approvals of State aid schemes and ad hoc rescue measures for banks (see European Commission 2008c), the modalities and pricing of recapitalisations of financial institutions (European Commission 2008f and European Central Bank 2008c and 2008d); or the specific principles for bank asset support measures and the treatment of impaired assets (European Commission 2009a and European Central Bank 2009)

These policy coordination measures have not been limited to the banking sector. The Commission also stepped in to sustain the real economy by adjusting its framework for state aid to support access to finance. Under this framework, state aid rules are applied "in a way that achieves maximum flexibility for tackling the crisis while maintaining a level playing field and avoiding undue restrictions of competition" (European Commission 2009b). Moreover, in December 2008, the European Council agreed an EU-wide economic stimulus of around $€ 200$ billion. The so-called 'European Economic Recovery 
Plan' (European Commission 2008e) was made up of budgetary expansion by Member States of $€ 170$ billion and EU funding in support of immediate action of $€ 30$ billion.

However, a certain scepticism persists among observers whether this was a genuine $E U$ response or whether it was not rather the mere coordination by the EU of national responses (Glöckler 2009). For example, with respect to fiscal policy, the principles and guidelines of the European Economic Recovery Plan were rather vague, leaving the magnitude and timing of fiscal impulses mainly to the discretion of national governments (Quaglia, Eastwood and Holmes 2009: 83). In the field of competition policy, the European Commission could not prevent that the rescue packages e.g. for banks and in the auto industry were to a large extent organised along national lines. Also in institutional terms, as former Commission President Jacques Delors critically argues, "when the crisis actually began, it seemed (...) to prove the intergovernmental method over the EU method (...) the fact that the initiative came from governments and not from the EU institutions will weigh heavily in the future" (Delors 2010: 17). Indeed, the measures of the Paris Declaration (see box 2) were very much driven by national governments. Some observers point out that the Commission did not play a central role in this initiative, though it provided support via its existing infrastructure for cooperation among governments.. In that sense, the fact that an EU umbrella could be opened upon the urging of the Commission as cover for the agreed set of measures had more to do with the coincidence of the EU presidency in the hands of an activist French government, rather than a genuine capacity of action of the supranational governance structures (Glöckler 2009).

What do these examples of collective action show? Rational choice theory would have predicted, under the severe circumstances in which Member States found themselves, a myopic, protective, national-interest-first policy response, with little regard for the negative spill-overs to the other EU and euro area countries. However, there has been no meltdown of EMU. The EU/EMU framework has reacted in a pragmatic and flexible manner to the extraordinary conditions which it was faced with. One of the main reasons why the crisis has not deteriorated into a 1903s-style spiral of 'beggar-thy-neighbour' policies was the existence of supranational institutions able to shape Member States' behaviours. Member States agreed to comply with some common minimum rules when trying to mitigate the effects of the crisis. Through the issuance of common guidelines, Union institutions thus did play a significant role in remedying the 'collective action dilemma'. 
Though bearing in mind some caveats, one can still argue that the EU's decision-making processes functioned quite smoothly during the financial crisis. By contrast, the episode of the sovereign debt crisis exemplified how an institutional framework based on rules and without sufficient scope for discretion over joint action displayed deficiencies in managing diverging national interest and perspectives so as to deliver a timely, determined and ultimately market-calming policy response.

\subsection{The ad hoc response of EMU to the sovereign debt crisis}

While, in the early stages of the crisis, shocks came mainly from 'outside', in the form of common disturbances to the financial sector that affected all Member States, the focus of the crisis shifted early 2010 to shocks coming from 'inside'. At stake were failings of the governments themselves whose adverse implications were magnified by the markets. A coordinated response proved much harder to come by. Euro area Member States were expected by financial markets, unless they allowed their common currency to be exposed to unprecedented stresses, to act in a way that had not been assumed in the EMU framework, i.e. to provide financial support to each other to ensure the financial and economic stability of the whole euro area. But even more than that: the very foundation of monetary union expressly excluded that Member States assume each others liabilities, via the "no bail-out" clause (Article 125 TFEU). This implied that the euro area had no contingency plan for providing financial assistance to one of its members (Greece). Instead, the euro area had to coordinate 16 different countries who shared no prior consensus on what balance should be struck between creating market impact, protecting taxpayers and limiting moral hazard.

In this context, the euro area response resembled more of an ad hoc response rather than a structured process. Due to the shortcomings of the EMU framework, domestic political interests came to the forefront and figured prominently in official communication, with detrimental effects on the financial markets. This translated into negative feedback loops between markets and policy actions. Markets looked to euro area governments to provide a unified direction, and reacted violently when political processes failed to deliver or resulted in disorderly communication from European policy-makers. Indeed, empirical evidence shows a correlation between daily spreads for 10-year government debt and significant political events (Carmassi and Micossi 2010). Graph 7 suggests that specific events, accompanied by inconsistent statements of politicians at critical junctures, may have deepened the crisis by casting further doubt in markets about the ability of the euro area to coordinate itself. 


\section{Chart 7. Problematic interaction between politics and markets}

Yields on Greek 2-year sovereign bonds

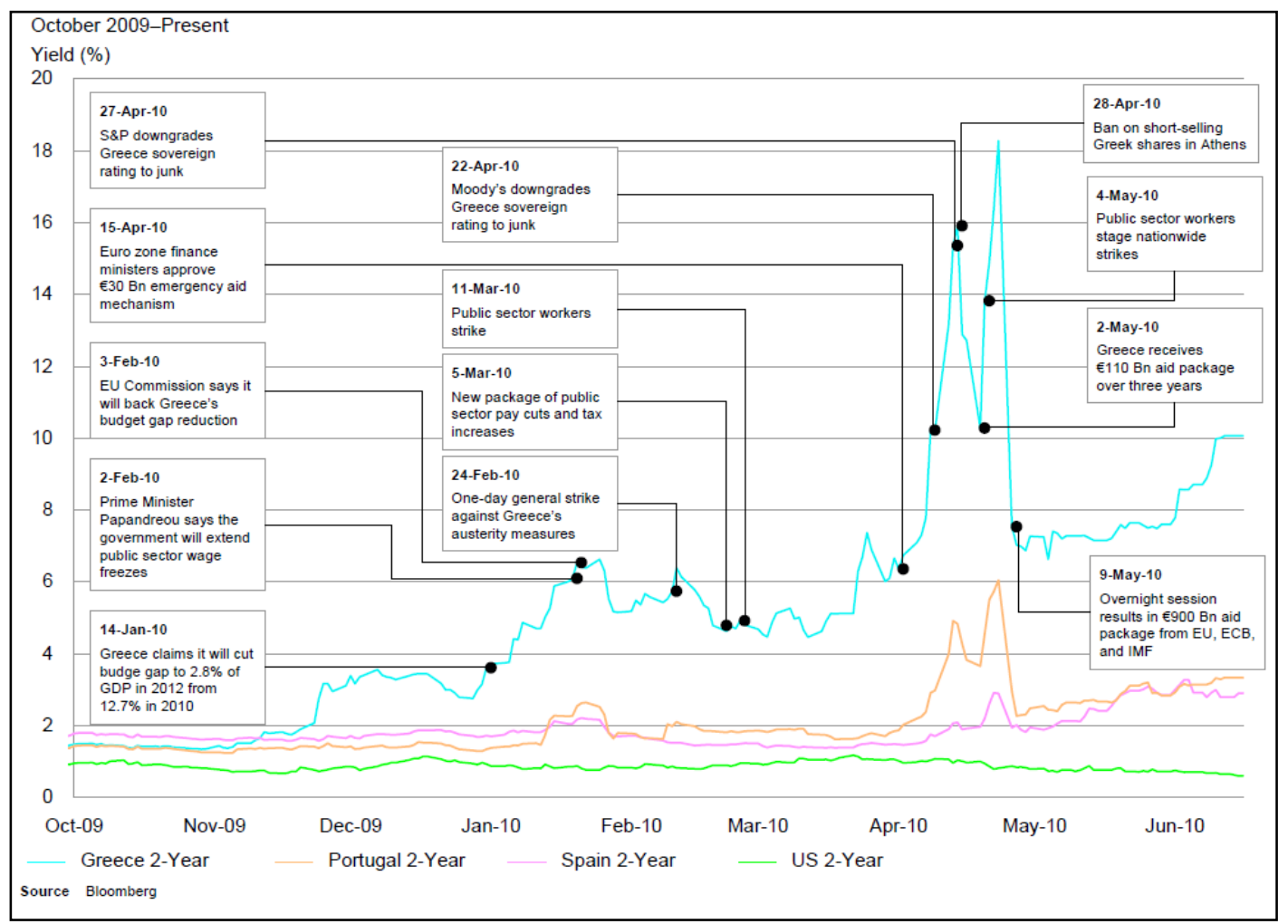

Source: Morgan Stanley Quarterly Short-Term Credit Market Update, $4^{\text {th }}$ Quarter 2010

Even the $€ 110$ billion package of bilateral loans to Greece of 2 May $2010^{16}$ failed to reestablish market confidence and was paradoxically followed by increased market volatility and soaring bond spreads. One answer could be that the ad hoc nature of the euro area's crisis response led markets to continuously doubt its credibility, creating a self-fulfilling downward spiral. Concerns about fiscal sustainability even began to spread to larger euro area countries. Not until the far-reaching policy decisions of the weekend of 7-9 May 2010 were euro area governments able to break this loop and get ahead of the curve. On this decisive weekend, the EU finally responded by creating two new crisis management instruments: the European Financial Stabilisation Mechanism (EFSM) and the European Financial Stability Facility (EFSF). These two mechanisms did not breach the aforementioned non bail-out clause because Member States thereby did not assume liabilities but instead provided loans under strict conditionality. 
On 9 May 2010, the ECOFIN Council adopted a Regulation (No 407/2010) setting up the EFSM. It allows the Commission to raise up to €60 billion on behalf of the EU for lending to EU Member States experiencing or being threatened with severe economic or financial disturbances. EFSM financial assistance is subject to strong policy conditionality and takes place in the context of joint EU-IMF programmes, on terms and conditions similar to those of IMF lending. The extension of the Regulation has to be reviewed every six months. Furthermore, euro area Member States, on an intergovernmental basis, established the EFSF as a limited liability company under Luxembourg law, with the purpose to provide loans to cover the financing needs of euro area Member States in difficulty, subject to strong policy conditionality in the context of joint euro area-IMF programmes. These loans are financed through the issuance of debt securities, guaranteed up to a total of $€ 440$ billion by euro area Member States on a pro rata basis (see chart 8). Finally, the IMF is expected to provide financing amounting to at least half as much as the euro area contribution to each programme, on terms and conditions in line with recent European programmes. ${ }^{17}$

Chart 8. How the EFSF works

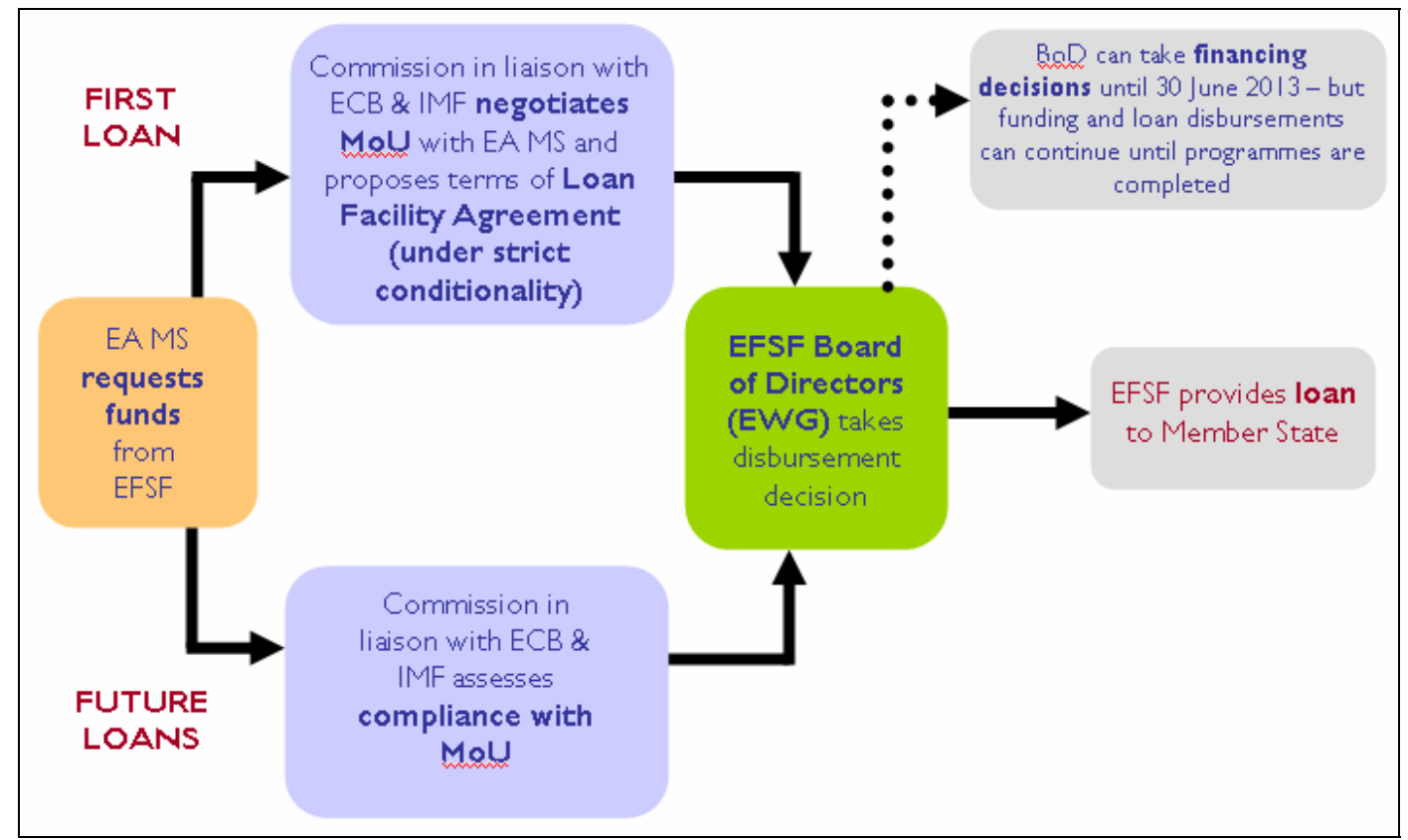

The euro area policy response to the sovereign debt crisis thus provides further evidence for the types of institutional change observed since 1999, namely layering. In fact, while it

\footnotetext{
${ }^{16}$ In May 2010, euro area governments and the IMF decided, under stringent conditionality, to grant Greece a $€ 110$ billion loan, consisting of $€ 80$ billion of bilateral loans from euro area countries and an IMF contribution of $€ 30$ billion.

${ }^{17}$ For a more comprehensive overview, see also ECB (2010d).
} 
is from a policy perspective a major innovation, the creation of the EFSM and EFSF amounts - in institutional terms - to the introduction of new layers, added on top of the existing set-up, and relying on already functioning infrastructures (EWG as Board of Directors of the EFSF, EIB to handle treasury services). This demonstrates that, even when subject to a severe crisis, EMU continues to evolve in an incremental way.

Setting up the EFSF was instrumental in restoring market confidence, but it is only a temporary solution. A permanent crisis management framework would be preferable to relying on ad hoc arrangements, which - as was demonstrated by the Greek case - run the risk of creating uncertainty in markets and reinforcing volatility. Naturally, the precise design of any such permanent framework would need to minimise the moral hazard that is inherent in any ex ante financial assistance scheme (ECB 2010c).

\section{Taking stock and looking forward}

Looking at the first twelve years of existence of EMU through the lenses of new institutionalism, what lessons can be drawn? How can we explain the rapidly changing assessments of EMU outlined in the introduction? And what is the likely impact of the crisis on the institutional development of EMU in the coming years? The subsequent sections will address these two questions.

\subsection{Has EMU passed the test?}

Even though new institutionalism takes a broad definition of "institutions" as covering formal institutions and rules as well as informal practices, a more refined differentiation between the institutions as such and the system of rules and procedures helps explain and identify the strengths and shortcomings of the EMU institutional set-up. While institutions provided a flexible framework for interaction between the different parties involved, the implementation of the rule-based incentive system proved to be inadequate in view of the high level of economic interdependency within EMU.

On the one hand, the crisis has demonstrated the remarkable flexibility and resilience of the EMU framework. As outlined in Section 2, it has been able to evolve gradually in "normal times" through the processes of layering and redirection without requiring any Treaty change. Much of the Lisbon Treaty merely codified changes that had been introduced earlier on in practice. Most significantly, when they became massively stresstested with the outburst of the crisis, EMU institutions have been able to react swiftly to 
extraordinary circumstances. This has been made possible inter alia by an intensification of institutional relations within the existing set-up.

Also noteworthy in times of crisis was the exemplary cooperation between EU colegislators. This is well illustrated by the extremely swift adoption of a revised regulation establishing a facility providing medium-term financial assistance for Member States' balances of payments (EU Council 2009). It aimed at raising the ceiling for the outstanding amount of loans to be granted to Member States from EUR 25 billion to EUR 50 billion. ${ }^{18}$ This revision was of critical importance given the severity of the crisis in certain non euro area Member States. In April-May 2009, the legislative procedure (which included the adoption of an opinion by the European Parliament and by the ECB) was completed within 40 days. While the EU machinery is often blamed for its slowness, this example demonstrated that the EU institutions are capable of reacting quickly and of cooperating with each other when conditions urgently require it.

However, this flexibility and resilience were not sufficient to address the fundamental mismatch between the level of policy interconnectedness and the level of institutional development prevailing within EMU. While euro area economies have become more and more closely interlinked, the institutional set-up has proved to be insufficiently developed in the field of economic governance. To start off, the EU, as a "community of law" resting on the principle of "mutual sincere cooperation” between its institutions (Art. 13.2 TEU), was fundamentally ill-equipped to countenance the possibility of an outright defiance of common rules, e.g. in the form of persistent fraudulent accounting and intentionally defective statistics that violated agreed standards. Moreover, the existing governance framework did not provide euro area Member States the right incentives, be it sanctions or rewards, to internalise the constraints of monetary union. The fact that economic policy was predominantly a national responsibility militated in favour of "non-interference" in other countries' economic policy decisions. This translated into insufficient peer pressure, reluctance to give early warnings or precise recommendations, and procedures - like the Excessive Deficit Procedure - which dragged on for many months. This was combined with a weakening of market discipline, as reflected in the low and converging levels of government bond yields over the first twelve years of the euro. As a result of these two factors, Member States did not take sufficiently into account the externalities of their economic policies (i.e. the implications for the rest of the euro area). In line with rational choice theory, national governments were rather focused on domestic concerns. In fact, this 
phenomenon could be observed since the very creation of EMU. However, its concrete and dire consequences became apparent only with the outburst of the sovereign debt crisis.

This helps to reconcile the sudden shifts in the assessment of EMU with its gradual institutional evolution (respectively outlined in Section 1 and 2). In its first decade of existence, EMU was largely praised, notwithstanding its weaknesses. Some - especially the ECB (2008a) - warned against the fiscal and macroeconomic imbalances, but policy makers, economic agents, and, most relevantly, financial markets chose to ignore. The institutional framework was thus largely considered as being 'fit for purpose'. With the outburst of the crisis, the risks that had existed since the early days of EMU have abruptly materialised. Observers have then suddenly focused on the shortcomings of EMU, some even going as far as predicting its meltdown should no reform be undertaken (Münchau 2010). One can conclude from these observations that, similarly to financial markets, the assessment of EMU is characterised by a certain degree of procyclicality - successively downplaying and overemphasising its weaknesses, depending on the cycle.

The most topical question that arises from this stock-taking exercise is whether the crisis, which brought such important shortcomings to the fore, will spur the appropriate institutional reform.

\subsection{The impact of the crisis on EMU: will the crisis be 'wasted'?}

It has been said that "a crisis is a terrible thing to waste" ${ }^{19}$. In a similar vein, expressions such as "critical juncture” or "window of opportunity" have flourished in 2010 in public pronouncements of European policy-makers. Empirically, one can observe a number of signs, both in the field of economic governance and of financial supervision, indicating that the crisis has provided a genuine reform impetus.

On the one hand, the so-called 'Van Rompuy Task Force' was established in March 2010 by the European Council. It was chaired by the President of the European Council and composed of representatives of the Member States, the rotating Presidency and the ECB. Its official mandate was to "present to the Council (...) the measures needed to reach the objective of an improved crisis resolution framework and better budgetary discipline, exploring all options [emphasis added] to reinforce the legal framework" (European Council 2010a). It recognised the need to take a broad view of governance that

\footnotetext{
${ }^{18}$ This ceiling had been already raised from EUR 12 to EUR 25 billion in early December 2008.

${ }^{19}$ Paul Romer, November 2004
} 
encompasses fiscal policy, competitiveness and crisis management. It delivered its report on 21 October 2010, while the Commission (2010 b-g) presented its legislative proposals on 29 September 2010 (see an overview of the main innovations in Table 2).

Among the numerous proposals presented by Member States and EU institutions in the framework of the Van Rompuy Task Force, some were unconceivable in "normal times" as they touch the very core of national sovereignty. For example, Germany and France suggested in their joint proposal the suspension of voting rights for countries not complying with the Stability and Growth Pact (Lagarde and Schäuble 2010). Several Member States also proposed the creation of a Eurobond. These two proposals are rather far-reaching in terms of loss of national sovereignty. Before the outburst of the crisis, they could only be found in the academic realm, certainly not on the EU political agenda. The crisis has thus extended the boundaries of the public debate beyond what was politically conceivable under normal circumstances.

Table 2. Main innovations of the Commission's legislative proposals and the Van Rompuy Task Force Report

\begin{tabular}{|c|c|c|}
\hline & $\begin{array}{l}\text { European Commission's legislative } \\
\text { proposals }\end{array}$ & Van Rompuy Task Force Report \\
\hline $\begin{array}{c}\text { Fiscal } \\
\text { Surveillance }\end{array}$ & $\begin{array}{l}\text { - Notion of "prudent fiscal policy-making” } \\
\text { - Operationalisation of debt criterion through } \\
\text { the adoption of a numerical benchmark } \\
\text { - Reverse voting mechanism for the } \\
\text { imposition of sanctions } \\
\text { - Graduated financial sanctions for euro area } \\
\text { member states (interest-bearing deposit, non } \\
\text { interest-bearing deposit, fines) } \\
\text { - Minimum requirements for national fiscal } \\
\text { frameworks }\end{array}$ & $\begin{array}{l}\text { - Reputational and political } \\
\text { sanctions: enhanced reporting } \\
\text { requirements, surveillance } \\
\text { missions, public report to the } \\
\text { European Council } \\
\text { - Measures to strengthen Eurostat } \\
\text { - Set of non binding standards for } \\
\text { national fiscal frameworks }\end{array}$ \\
\hline $\begin{array}{l}\text { Macroeconomic } \\
\text { surveillance }\end{array}$ & $\begin{array}{l}\text { - Alert mechanism through a scoreboard (set } \\
\text { of indicators, alert thresholds) } \\
\text { - Preventive surveillance based on discussions } \\
\text { with Member States and in-depth reviews } \\
\text { - Excessive Imbalance Procedure (involving } \\
\text { financial sanctions for euro area member } \\
\text { states) }\end{array}$ & \\
\hline
\end{tabular}

Source: Own compilation

Another telling example of this impetus for change is the ongoing reform of the financial supervisory architecture. Any reform endeavour in this field has always been strongly resisted by national authorities. By exposing important failures in the Lamfalussy structures, the crisis has clearly accelerated their overhaul and is bringing about a new financial supervisory architecture, i.e. the European System of Financial Supervision (see Chart 9). The package agreed upon by the EU co-legislators in autumn 2010 foresees the creation of three European micro-supervisory Authorities (ESAs) - each of them being in charge of 
overseeing a sector of the financial system (Banking, Insurance, Securities and Markets). The ESAs are responsible for developing technical standards with a view to a single EU rulebook and have power to ensure the consistent application of Union rules across national jurisdictions. In addition, a new body, i.e. the European Systemic Risk Board (ESRB), was created. The ESRB is responsible for macro-prudential oversight of the European financial system as a whole - an area which was clearly missing before and during the crisis. It monitors and assesses potential threats to financial stability and has the power to address warnings and recommendations to a national or European authority.

\section{Chart 9. The new design of the financial supervisory architecture}

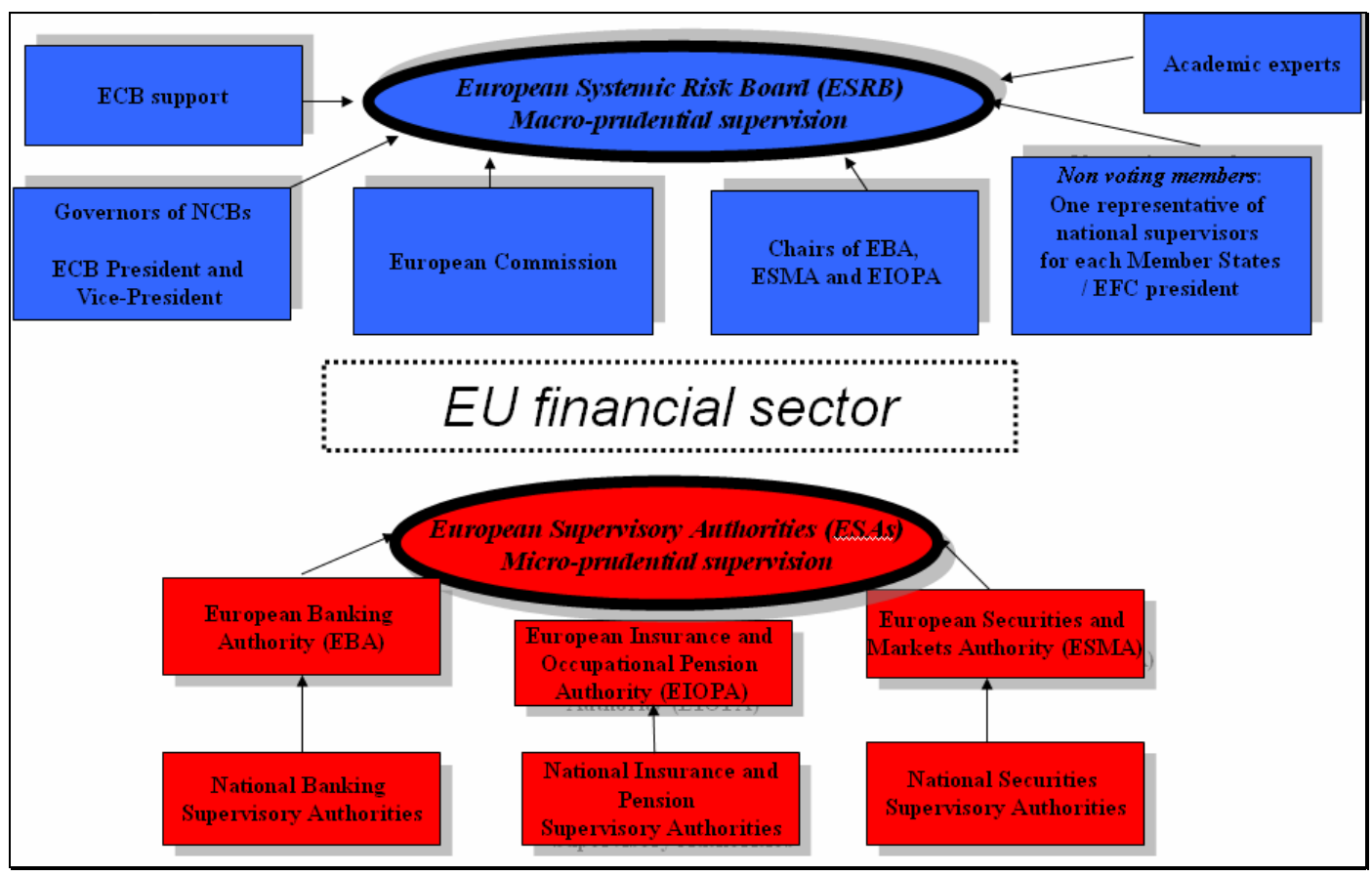

All of this seems to indicate that the crisis will accelerate institutional development. Does that mean that the EU and the euro area are at the brink of moving towards a radically new governance framework for their economies and financial sectors, as demanded by some observers (De Grauwe 2010)? In fact, many institutionalists divide the flow of historical events into periods of continuity punctuated by critical junctures, i.e. moments when substantial institutional change takes places thereby creating a "branching point" from which historical development moves into a new path (Hall and Taylor, 1996: 942). Does the crisis represent such a "branching point" and is EMU moving into a new path?

Probably not. In all likelihood, a fundamental overhaul of the existing EMU set-up cannot be expected and the institutional changes to be anticipated will at best be of a rather 
gradual nature. During the first decade of existence of EMU, the institutional framework has evolved gradually, subject to a certain path dependency, and institutions have proved to be sticky. The evidence in crisis response and since then seems to confirm that institutionalism will continue to be a valid theory to explore the dynamics of EMU in the years to come. In other words, the institutional framework will continue to evolve by the processes of layering and redirection.

As regards economic policy coordination and surveillance, the Europe 2020 Strategy is a prime illustration of this trend: it mainly consists of streamlining and redirecting the Lisbon Strategy and its existing policy instruments. National Reform Programmes continue to play a key role under Europe 2020 similar to their role in the Lisbon Strategy. The Integrated Guidelines for Economic and Employment policies, an instrument already foreseen in Treaty, have been revised to reflect the new priorities of the Europe 2020 Strategy. Their number has been reduced to 10, from 24 under the Lisbon Strategy.

Chart 10. Governance of the Europe 2020 Strategy

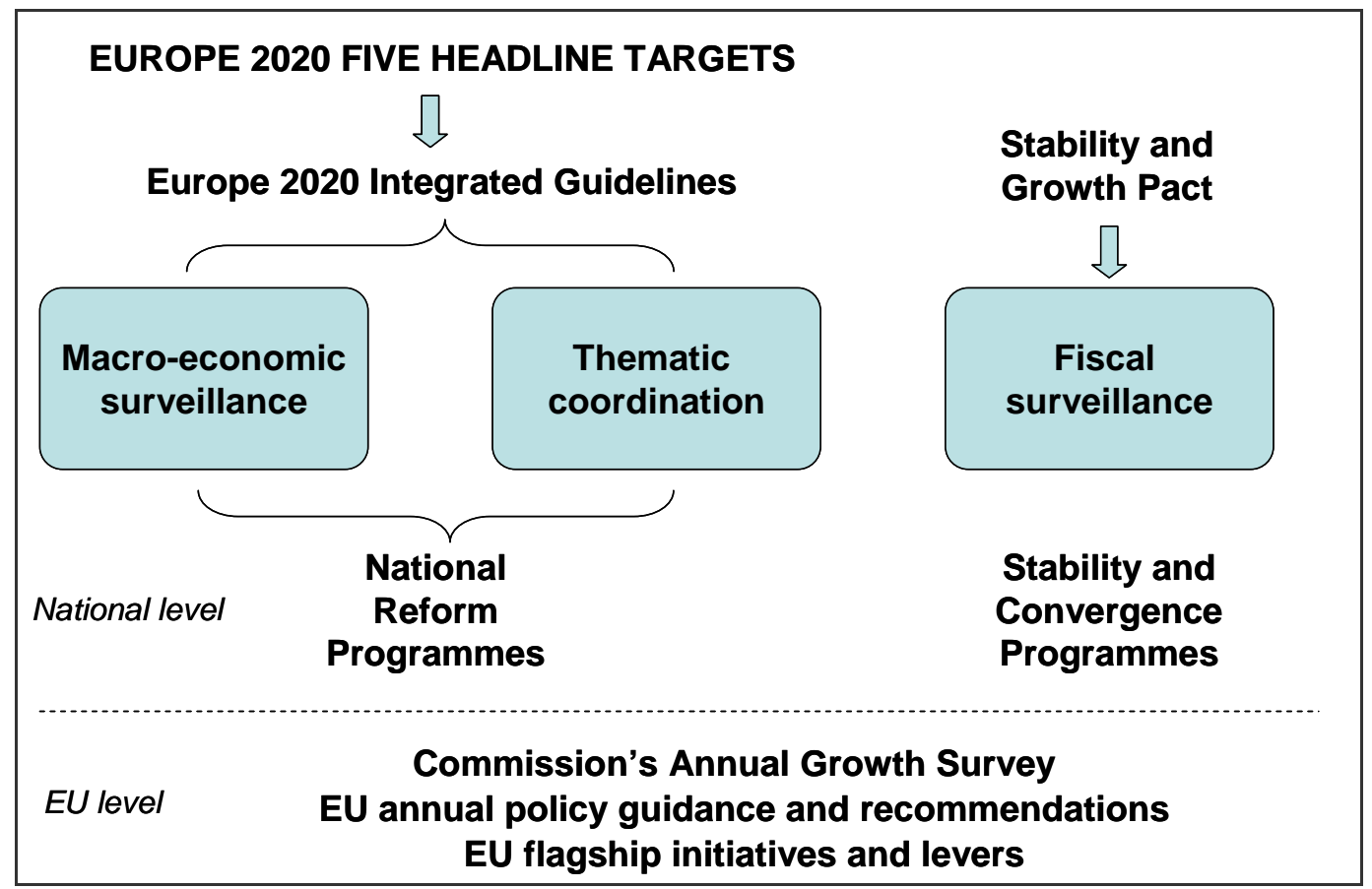

As regards more specifically the debate on economic governance, it has become soon clear that, at least in the short-term, no new institution would be created, and no step change would occur as regards the repartition of competences between the EU and Member States. As an example, the European Council conclusions of 16-17 December 2010 "agreed on the text of a limited amendment to the Treaty on the establishment of a future permanent mechanism to safeguard the financial stability of the euro area as a whole” (emphasis added) 
to be adopted by the simplified revision procedure (European Council 2010b). Using the typology of institutional change, one can argue that the reform of economic governance will be most likely dominated by the redirection of existing instruments. In fact, the six legislative proposals of the Commission do not conceive a governance framework completely ex novo, but rather rely on the existing SGP. On the fiscal side, the Commission proposes to revise existing Council regulations initially adopted in $1997^{20}$, while the newly created framework for macroeconomic surveillance is clearly inspired by the SGP (e.g. preventive and corrective arm, Excessive Imbalance Procedure).

A closer look at the financial supervisory reform also shows the incremental nature of the changes. The proposed legislation does not create the ESAs from scratch but upgrades the existing 3L3 committees by transforming them into authorities with legal personality and enhanced competences. As for the ESRB, it should be underlined that this new body will have no legally binding powers and that it could be seen as an umbrella organisation gathering existing institutions (mostly national central banks and national supervisors of the EU-27). This is once again an example of how the institutional architecture of EMU evolves by the process of layering. The existence of a legislative review clause confirms that the financial supervisory architecture has not reached its final shape and will be subject to further incremental changes.

Institutionalism also provides interesting insights by arguing that gains from cooperation are the main determinant of institutional development (Hall and Taylor 1996: 945-946). Applying this assumption to the financial supervisory reform allows to understand why a 'big-bang' approach - such as the creation of a single supervisory authority - cannot be expected. The crisis has certainly revealed the costs of insufficiently harmonised financial regulation and supervision and thereby demonstrated the benefits of more integrated structures. For instance, the severe difficulties encountered by the Irish banking sector - and consequently by the Irish government - exemplified the inadequacy of a purely national approach to crisis management and resolution. When a national banking system encounters difficulties, national taxpayers alone may not be able to absorb the shock. This may imply contagion effects and thus eventually requires a European response. As the Turner Review of the UK Financial Services Authority points out,

\footnotetext{
${ }^{20}$ Council Regulation (EC) No 1466/97 of 7 July 1997 on the strengthening of the surveillance of budgetary positions and the surveillance and coordination of economic policies; Council Regulation (EC) No 1467/97 of 7 July 1997 on speeding up and clarifying the implementation of the excessive deficit procedure
} 
"the current arrangements, combining branch passporting rights, home country supervision, and purely national deposit insurance, are not a sound basis for the future regulation and supervision of European cross-border retail banks (...) Sounder arrangements require either increased national powers, implying a less open single market, or a greater degree of European integration” (FSA 2009: 101).

All in all, there seems to be a general consensus among EU institutions on the gains stemming from the "more Europe" option. At the same time, these benefits are associated with losses of national competences. Following a rational choice logic, Member States will agree to a deeper level of integration until the point where their marginal utility (i.e. gains from more integrated supervision) is outweighed by the marginal cost (i.e. loss of competences). This is well illustrated by the compromise over the financial supervisory reform, where the direct supervision of cross-border financial institutions by the ESAs ${ }^{21}$ and the application of the so-called 'safeguard clause' ${ }^{22}$ were among the most contentious issues. In these two cases, a significant loss of competences of national supervisory authorities and a limitation of national fiscal sovereignty were respectively at stake. As Member States are still reluctant to transfer too many competences to the EU level, the financial supervisory architecture could not be subject to any "revolutionary" change. This illustrates well the force of one 'reproduction mechanism', namely the lack of interest in change by dominating actors.

These empirical observations are fully in line with one of the main predictions of the new institutionalist literature, namely that policy-makers cannot go for a "breakdown and replacement" single-handed reform because this would not be sustainable and would eventually lead to a reaction bringing back old institutions (Guardiancich 2009). Institutional reforms therefore have inbuilt bias towards incremental change, as the more sustainable and efficient form, rather than "clean slate approaches”. Even the most severe financial and economic crisis since the end of the Second World War is likely to verify this prediction.

\footnotetext{
${ }^{21}$ The European Parliament was in favour of a supervisory arrangement according to which the European Supervisory Authority would "take over the supervision of financial institutions meeting the systemic risk criteria to the extent they could jeopardise the stability of the Union financial system, where a national authority has failed to exercise its powers" (European Parliament 2010: 12). Such a direct supervision has been so far opposed by the EU Council.

${ }^{22}$ The Commission's proposal states under Article 23 that "the Authority shall ensure that no decision adopted under Articles 10 and 11 [in case of an emergency situation or of a disagreement between national authorities] impinges in any way on the fiscal responsibilities of the Member States” (European Commission 2009c). The exact scope and modalities of application of this safeguard clause are subject to tough negotiations between the European Parliament and the Council.
} 


\section{Conclusion}

To sum up, the crisis will accelerate institutional development, but will do it only in a gradual way. Even when subject to a massive stress-test, EMU seems to follow the same logic of institutional change than in its first eight years. Despite the very different external economic conditions, this paper has identified at least one common feature between the two periods examined: no matter whether in 'fair weather' or in 'stormy' times EMU evolves by gradual on-path changes. However, this does not mean that the crisis will be 'wasted'.

First of all, one has to put the institutional evolution of EMU analysed throughout this paper into historical perspective. In view of the high-stakes experiment it represents, EMU is a very young endeavour and - by any historical standards - has been evolving rather swiftly. For example, in the US the necessity for a common central bank only led to action with the Federal Reserve Act of 1913. Therefore, the importance of the changes observed since the creation of EMU, and in particular during the financial crisis, has to be assessed against the historical scale commensurate with such endeavours (i.e. decade-wise rather than year-wise) and should not be underestimated.

Secondly, the fact that EMU will broadly remain on the same path decided in Maastricht is not negative as such. The decisive issue to bring EMU back to sustainable growth and fiscal discipline is to address the main shortcoming of the EMU framework so far, i.e. the internalisation of the EMU dimension into Member States' rational choices. This can be achieved while remaining on the same path and without going for a "big-bang approach". For example, the new supervisory framework will be successful if it succeeds in compelling its various components (especially the national supervisory authorities) to internalise the European dimension when exercising their prerogatives.

In a similar vein, in the field of economic governance, in order to ensure real commitment from policy makers to "regard their economic policies as a matter of common concern" (Article 121 TFEU), the institutional framework must be enhanced to provide the right incentives and to ensure compliance. This should apply to both preventive and corrective arms of surveillance processes. Given the crucial importance of national fiscal frameworks, the EU could incentivise the adoption of national rules and/or institutions that encourage and enforce fiscal discipline. As regards the corrective arm, the idea of using the EU budget for sanctions (but only to the extent that it does not hurt individual entitlements - European Commission 2010) would force Member States which benefit from the EU budget to take into account the externalities of their fiscal decisions for the 
rest of the euro area when calculating their 'utility'. The design of any permanent crisis management framework should be governed by similar considerations. Non-compliance with conditionality should be met with sanctions, escalating to de facto loss of fiscal autonomy. This would ensure that the recourse to any crisis resolution mechanism would be sufficiently unattractive and would limit moral hazard. Financing the mechanism would also sharpen the incentives for all euro area countries to exercise effective peer pressure and surveillance to prevent crises. This would shape expectations of fiscally undisciplined governments about how other Member States are likely to behave in case of unsound fiscal policies and thereby shape their own strategic calculations.

Such an approach would contribute to match the level of institutional development with the level of policy interconnectedness. The governance framework would better reflect the intensity of economic and financial interdependency within the EU and, in political terms, the reality of the euro area "Schicksalgemeinschaft" (Trichet 2010). 


\section{BIBLIOGRAPHY}

Bergsten, F., 2005. The Euro and the Dollar: Toward a Finance G-2?. In: Posen, A.S. Ed., The Euro at Five: Ready for a Global Role?, Institute for International Economics, Washington, D.C., pp.27-39.

Bernanke, B., 2008. Panel Statement. In: Mackowiak, M., Mongelli, F., Noblet, G. and Smets F. Eds.. The euro at ten - Lessons and challenges. European Central Bank, Frankfurt.

Bouzou, N., 2010. Stratégie pour une réduction de la dette publique française. Note de la Fondapol, Février.

Buti, M. and Gaspar, V., 2008. The first ten years of the EU. VoxEU, 24 December.

Carmassi, J. and Micossi, S., 2010. The role of politicians in inciting financial markets to attack the eurozone. EuropEos, CEPS, Brussels, No.4.

Chang, M., 2009. Monetary Integration in the European Union. Palgrave MacMillan.

De Grauwe, P. , 2010. How to embed the Eurozone in a political union? Vox EU, 17 June.

De Haan, J., Oosterloo, S. and Schoenmaker, D., 2009. European Financial Markets and Institutions. Cambridge University Press.

Delors Report, 1989. Report on Economic and Monetary Union in the European Community. Report to the European Council.

Delors, J., 2010. The Economic and Monetary Union needs a new impetus. In: Leuro en 2019, Revue déconomie financière, January 2010.

Delpla, J. , 2010. Réduire la dette grâce à la Constitution. Note de la Fondapol. Février.

Deroose, S., Hodson, D. and Kuhlmann, J., 2008. The Broad Economic Policy Guidelines: Before and After the Re-launch of the Lisbon Strategy. Journal of Common Market Studies 46/4, 827-848.

Dominguez, K. M. E., 2006. The European Central Bank, the Euro, and Global Financial Markets. The Journal of Economic Perspectives 20 4, 67-88.

Dyson, K., 2000. The Politics of the Euro-Zone: Stability or Breakdown?. Oxford: Oxford University Press.

European Central Bank, 2001. Monthly Bulletin. November, Frankfurt am Main.

European Central Bank, 2003. Monthly Bulletin. May, Frankfurt am Main.

European Central Bank, 2008a. Monthly Bulletin $10^{\text {th }}$ Anniversary of the ECB. May, Frankfurt am Main.

European Central Bank, 2008b. The International Role of the Euro. Frankfurt am Main.

European Central Bank, 2008c. Recommendations of the Governing Council of the European Central Bank on government guarantees for bank debt. 20 October.

European Central Bank, 2008d. Recommendations of the Governing Council of the European Central Bank on the pricing of recapitalizations. 20 November.

European Central Bank, 2009. Guiding principles for bank asset support schemes. 25 February.

European Central Bank, 2010a. The ECBs Relations with European Union Institutions and Bodies - Trends and Prospects. Monthly Bulletin, January. Frankfurt Am Main.

European Central Bank, 2010b. Measures taken by euro area governments in support of the financial sector. Monthly Bulletin. April, Frankfurt Am Main.

European Central Bank, 2010c. Reinforcing economic governance in the euro area. June, Frankfurt am Main

European Central Bank, 2010d. Recent developments in EU financial stability arrangements, Monthly Bulletin, December, pp.82-83

European Commission, 2006a. Public Finance Report. Luxembourg: Office for Official Publications of the European Communities.

European Commission, 2006b. EU Economy Review/ Luxembourg: Office for Official Publications of the European Communities.

European Commission, 2007. Keeping up the pace of change: Strategic report on the renewed Lisbon strategy for growth and jobs: launching the new cycle 2008-2010. Communication from the Commission to the Spring European Council, COM07 803 final.

European Commission, 2008a. One currency for one Europe: The road to the euro. Luxembourg: Office for Official Publications of the European Communities. 
European Commission, 2008b. EMU@10: successes and challenges after 10 years of Economic and Monetary Union. Luxembourg: Office for Official Publications of the European Communities.

European Commission, 2008c. The application of State aid rules to measures taken in relation to financial institutions in the context of the current global financial crisis, Communication of 13 October 2008.

European Commission, 2008d. Proposal for a Directive of the European Parliament and the Council amending Directive 94/19/EC on Deposit Guarantee Schemes as regards the coverage level and the payout delay. COM2008661, 15 October.

European Commission, 2008e. A European Economic Recovery Plan. Communication to the European Council. COM2008 800, 26 November.

European Commission, 2008f. Recapitalisation of financial institutions in the current financial crisis: limitation of the aid to the minimum necessary and safeguards against undue distortions of competition. Communication of 5 December 2008.

European Commission, 2009a. Communication on the Treatment of Impaired Assets in the Community Banking Sector. Communication of 25 February 2009.

European Commission, 2009b. Temporary Community framework for state aid measures to support access to finance in the current financial and economic crisis. Communication 2009/C 83/01, 7 April 2009.

European Commission, 2009c. Proposal for a regulation of the European Parliament and the Council establishing a European Banking Authority. COM2009 501, 23 September.

European Commission, 2009d. Sustainability Report 2009. European Economy 9.

European Commission, 2010a. Enhancing economic policy coordination for stability, growth and jobs - Tools for stronger EU economic governance. Communication of 30 June 2010.

European Commission, 2010b. Proposal for a regulation of the EP and Council amending Regulation EC No 1466/97 on the strengthening of the surveillance of budgetary positions and the surveillance and coordination of economic policies, 29 September.

European Commission, 2010c. Proposal for a Council regulation amending Regulation EC No 1467/97 on speeding up and clarifying the implementation of the excessive deficit procedure, 29 September.

European Commission, 2010d. Proposal for a Council directive on requirements for budgetary frameworks of the Member States, 29 September.

European Commission, 2010e. Proposal for a regulation of the EP and Council on the prevention and correction of macroeconomic imbalances, 29 September.

European Commission, 2010f. Proposal for a regulation of the EP and Council on enforcement measures to correct excessive macroeconomic imbalances in the euro area, 29 September.

European Commission, 2010g. Proposal for a regulation of the EP and Council on the effective enforcement of budgetary surveillance in the euro area, 29 September.

EU Council, 2008. Conclusions of the Council on Economic and Financial Affairs, 7 October.

EU Council, 2009. Council Regulation EC No 431/2009 of 18 May 2009 amending Regulation EC No 332/2002 establishing a facility providing medium-term financial assistance for Member States balances of payments.

European Council, 2010a. Conclusions of the European Council, 25-26 March.

European Council, 2010b. Conclusions of the European Council, 16-17 December.

European Parliament, 2010. Report on the proposal for a regulation of the European Parliament and the Council establishing a European Banking Authority, Committee on Economic and Monetary Affairs, 3 June.

Feldstein, M., 1997. EMU and International Conflict. Foreign Affairs, November-December 766, 60-73.

Financial Services Authority, 2009. The Turner Review: A regulatory response to the global banking crisis. March.

Frankal, B., Oleaga, I. A. and Coussens, W., 2007. How Will the Treaty of Lisbon Affect EMU?. Euredia.

Fudenberg, D. and Tirole, J., 1992. Game Theory. Cambridge, Massachussets: The MIT Press.

Glöckler, G., 2009. Euro Area Governance and the Financial Crisis: New Quality or Flash-in-thepan?. In: Little, R. Ed., After the crisis: A new socio-economic settlement for the EU. London: Policy Network. 
Gourevitch, P. 1986. Politics in Hard Times: Comparative Responses to International Economic Crises. Ithaca: Cornell University Press.

Guardiancich, I., 2009. Institutional Survival and Return: Examples from the New Pension Orthodoxy. ETUI Working Paper 2009.08.

Haas, E., 1958, The Uniting of Europe, Stanford: Stanford University Press.

Hall, P.A and Taylor, R.C.R., 1996. Political science and the three new institutionalisms. Political Studies 44, 936-957.

Hodson, D., 2009a. EMU and Political Union: What, if anything, have we learned from 10 years of the euro?. Journal of European Public Policy, 16 (3), 508-526.

Hodson, D., 2009b. Reforming EU Economic Governance: A view from (and on) the principalagent approach. Comparative European Politics, 7 (4), 455-75.

Hodson, D., 2010. Economic and Monetary Union: An Experiment in New Modes of EU PolicyMaking. In: H. Wallace, M. Pollack and A. Smith Eds., Policy-Making in the European Union. Oxford: Oxford University Press.

Hodson, D. and Maher, I., 2001. The Open Method as a new Mode of Governance: the Case of Soft Economic Policy Co-ordination. Journal of Common Market Studies, 39 (4). 719-46.

Hodson, D. and Quaglia, L., 2009. European Perspectives on the Global Financial Crisis: Introduction. Journal of Common Market Studies, 475, 939-953.

Ioannou D., Ferdinandusse M., Lo Duca M., Coussens W., 2008, Benchmarking the Lisbon Strategy, ECB Occasional Paper Series, no. 85, June.

Irish Ministry of Finance, 2008. Government decision to safeguard Irish banking system. Statement of 29 September 2008.

Issing, O., 2010. The future of the euro: Will the success story continue?. In: L'euro en 2019. Revue d'économie financière, January.

Jaillet, P., Pisani-Ferry, J., 2010. Introduction, In: L'euro en 2019. Revue d'économie financière, January 2010.

Kastrop, C., Herres, H., Schneider, J., Hanke, B., Baumann, E., Snelting, M. and Dönnebrink, E., 2009. Reforming the Constitutional Budget Rules in Germany. Federal Ministry for Finance, September.

Koszerek, D., Havik, K., McMorrow, K. and Roeger,W., 2007. An Overview of the EU KLEMS Growth and Productivity Accounts. European Economy, Economic Papers No. 290, European Commission, Brussels.

Lagarde, C. and Schäuble, W. 2010. European Economic Governance: Franco-German paper. 21 July.

Lamfalussy, A. 2004. Central Banks and Financial Stability, Pierre Werner Lecture, Central Bank of Luxembourg, 26 October.

Lindberg, L., 1963. The political dynamics of European economic integration. Stanford University Press.

Lindner, J., 2003. Institutional Stability and Change: Two Sides of the Same Coin. Journal of European Public Policy, 10 (6): 912-935.

Martens, H. and Zuleeg, F., 2008. Where would we be now without the euro?. European Policy Centre Commentary, 14 October.

Menzie, C and Frankel, J., 2008. The Euro May Over the Next 15 Years Surpass the Dollar as Leading International Currency. Faculty Research Working Paper RWP08-016 Cambridge, MA: Harvard University, John F. Kennedy School of Government.

Münchau, W., 2010. The eurozone must take responsibility or it will split. Financial Times, 9 May.

Mundell, R., 1968. International Economics. New York: MacMillan.

North, D. C. and Weingast, B., 1989. "Constitution and Commitment: The Evolution of Institutional Governing Public Choice in Seventeenth-Century England". The Journal of Economic History, 49/4: 803-832.

North, D. C., 1990. Institutions, Institutional Change and Economic Performance. Cambridge University Press.

Nugent, N., 2006. The government and politics of the European Union. Palgrave Macmillan.

Official Journal, 2010. Treaty on the Functioning of the European Union. 30 March.

O’Sullivan, J., 2009. Special Report on the Euro-Area. The Economist, June 11. 
Padoa-Schioppa, T., 1982. European Capital Markets Between Liberalization and Restrictions in Money, Economic Policy and Europe. The European Perspectives Series, Commission of the European Communities, Brussels, 1985.

Papademos, L., 2008. Introduction. In: Mackowiak, M., Mongelli, F., Noblet, G. and Smets F. Eds. The euro at ten - Lessons and challenges. European Central Bank.

Pierson, P., 2000. Increasing Returns, Path Dependence, and the Study of Politics." American Political Science Review, 92 (2), 251-265.

Pierson, Paul \& Skocpol, Theda. 2002. "Historical Institutionalism in Contemporary Political Science”, in Ira Katznelson \& Helen V. Milner (eds). Political Science: State of the Discipline. New York: W.W. Norton: 693-721.

Pisani-Ferry, J. and Sapir, A., 2010. EU Banking Policies, Economic Policy, April.

Pisani-Ferry, J., 2010. Euro area governance: what went wrong in the euro area? How to repair it. Bruegel Policy Contribution, 8 June.

Posen, A., 2009. Geopolitical Limits to the euros global role. In: A. Posen and A. Sapir Eds.. The Euro at Ten: The next global currency?. Peterson Institute for International Economics, Washington, D.C, 85-102.

Proissl, W., 2010. Why Germany fell out of love with Europe. Bruegel Essay and Lecture Series.

Puetter, U., 2006. The Eurogroup. How a secretive circle of finance ministers shape European economic governance. Manchester: Manchester University Press.

Puetter, U., 2007. Intervening from outside: the role of EU finance ministers in constitutional politics. Journal of European Public Policy, 148, 1293-1310.

Quaglia, L., 2008. Committee Governance in the Financial Sector. Journal of European Integration, $303,565-580$.

Quaglia, L., 2009. The British Plan as a pace-setter : The Europeanization of banking rescue Plans in the EU ?. Journal of Common Market Studies, 47 5, 1063-1083.

Quaglia, L., Eastwood, R. and Holmes, P., 2009. The Financial Turmoil and EU Policy Cooperation in 2008. Journal of Common Market Studies, 47 Annual Review, 63-87.

Quaglia, L., 2010. Governing Financial Services in the European Union. Routledge, London.

Schaechter, A. and Barrios, S., 2008. The Quality of Public Finances and Growth. Economic Papers 337, European Commission, Brussels.

Schelkle, W., 2009. The Contentious Creation of the Regulatory State in Fiscal Surveillance. West European Politics 324, 829-846.

Schoenmaker, D. and Oosterloo, S., 2007. Cross-border issues in European financial supervision. In: D.G. Mayes and G. Wood Eds., The Structure of Financial Regulation. Routledge, London.

Secretariat of the European Convention, 2002. Mandate of the Working Group on Economic Governance. Brussels, CONV 76-02, 30.05.2002.

Steinmo, S and Lewis, O. 2007. Taking Evolution Seriously. ARENA Working Paper No. 19, Oslo.

Streeck, W.,Thelen, K., 2005. Beyond Continuity: Institutional Change in Advanced Political Economies. Oxford University Press.

Tobin, J., 1998. Currency Unions: Europe versus the United States. Policy Options, May, p.31-33.

Trichet, J.C., 2010. Hearing before the Committee on Economic and Monetary Affairs of the European Parliament, March.

Van Rompuy Task Force, 2010. Strengthening economic governance in the EU, Report of the Task Force to the European Council, 21 October.

Werner Report, 1970. Report to the Council and the Commission on the Realisation by Stages of Economic and Monetary Union in the Community. Luxembourg, 8 October. 